\title{
Inhibition of Prolyl Oligopeptidase Restores Spontaneous Motor Behavior in the $\alpha$-Synuclein Virus Vector-Based Parkinson's Disease Mouse Model by Decreasing $\alpha$-Synuclein Oligomeric Species in Mouse Brain
}

\author{
Reinis Svarcbahs, * ĐUlrika H. Julku, ${ }^{\star}$ and ๑Timo T. Myöhänen \\ Division of Pharmacology and Pharmacotherapy, University of Helsinki, FI-00014 Helsinki, Finland
}

\begin{abstract}
Decreased clearance of $\alpha$-synuclein (aSyn) and aSyn protein misfolding and aggregation are seen as major factors in the pathogenesis of Parkinson's disease (PD) and other synucleinopathies that leads to disruption in neuronal function and eventually to cell death. Prolyl oligopeptidase (PREP) can accelerate the aSyn aggregation process, while inhibition of PREP by a small molecule inhibitor decreases aSyn oligomer formation and enhances its clearance via autophagy in different aSyn overexpressing cell types and in transgenic PD animal models. In this study, we investigated the impact of chronic PREP inhibition by a small molecule inhibitor, 4-phenylbutanoyl-l-prolyl2(S)-cyanopyrrolidine (KYP-2047), on aSyn oligomerization, clearance, and underlying spontaneous motor behavior in a virus vectorbased aSyn overexpression mouse model 4 weeks after aSyn microinjections and after the onset of symptomatic forepaw bias. Following 4 weeks of PREP inhibition, we saw an improved spontaneous forelimb use in mice that correlated with a decreased immunoreactivity against oligomer-specific forms of aSyn. Additionally, KYP-2047 had a trend to enhance dopaminergic systems activity. Our results suggest that PREP inhibition exhibits a beneficial effect on the aSyn clearance and aggregation in a virus mediated aSyn overexpression PD mouse model and that PREP inhibitors could be a novel therapeutic strategy for synucleinopathies.
\end{abstract}

Key words: Parkinson's disease; prolyl oligopeptidase inhibitor; protein aggregation; serine protease; synuclein; synucleinopathies

\section{Significance Statement}

Alpha-synuclein (aSyn) has been implicated in Parkinson's disease, with aSyn aggregates believed to exert toxic effects on neurons, while prolyl oligopeptidase (PREP) has been shown to interact with aSyn both in cells and cell free conditions, thus enhancing its aggregation. We demonstrate the possibility to abolish motor imbalance caused by aSyn viral vector injection with chronic 4 week PREP inhibition by a potent small-molecule PREP inhibitor, 4-phenylbutanoyl-l-prolyl-2(S)-cyanopyrrolidine (KYP-2047). Treatment was initiated postsymptomatically, 4 weeks after aSyn injection. KYP-2047-treated animals had a significantly decreased amount of oligomeric aSyn particles and improved dopamine system activity compared to control animals. To our knowledge, this is the first time viral overexpression of aSyn has been countered and movement impairments abolished after their onset.

\section{Introduction}

Parkinson's disease (PD) is a neurodegenerative movement disorder that involves multiple neuronal systems and is character-

\footnotetext{
Received July 21, 2016; revised 0ct. 19, 2016; accepted 0ct. 21, 2016.

Author contributions: R.S., U.H.J., and T.T.M. designed research; R.S. and U.H.J. performed research; R.S. and U.H.J. analyzed data; R.S. and T.T.M. wrote the paper.

This work was supported by Academy of Finland Grants 267788 and 2737991, University of Helsinki research grants, and grants from the Jane and Aatos Erkko Foundation and the Sigrid Juselius Foundation to T.T.M. Authors would like to thank Susanna Norrbacka for excellent technical assistance.

*R.S. and U.H.J contributed equally to this work.

The authors declare no competing financial interests.

Correspondence should be addressed to T. Myöhänen, Division of Pharmacology and Pharmacotherapy, University of Helsinki, Fl-00014 Helsinki, Finland. E-mail: timo.myohanen@helsinki.fi.
}

ized by dopaminergic (DAergic) neuron loss in the substantia nigra (SN) preceded by the formation of Lewy bodies (LBs) (Braak and Braak, 2000; Spillantini and Goedert, 2000). LBs are used as the neuropathological hallmarks of PD (Baba et al., 1998; Kahle, 2008). The main component of these inclusions is misfolded and aggregated forms of $\alpha$-synuclein (aSyn) (Spillantini et al., 1997). Moreover, familial SNCA gene point mutations, duplications and triplications, correlate with severity and onset of PD (Singleton et al., 2003; Ibáñez et al., 2004; Fuchs et al., 2007; Langston et al., 2015). 
aSyn is an intrinsically disordered protein (Uversky, 2011) and, in contrast to many proteins involved in neurodegeneration that are distributed throughout the neuron, localizes specifically to the nerve terminals, with relatively little in the cell body, dendrites, or extrasynaptic sites along the axon (Bendor et al., 2013). Under physiological conditions, it is predominantly found in the presynaptic nerve terminals in high concentrations close to the synaptic vesicles (Iwai et al., 1995; Vekrellis et al., 2011), where it is thought to participate in vesicle trafficking, release, and recycling, thus directly modulating synaptic plasticity and function (Bellani et al., 2010). Various factors can initiate the misfolding and aggregation process of aSyn (Uversky, 2007), and aberrant aSyn negatively affects subcellular distribution of synaptic components (Bellucci et al., 2012) and alters synaptic dopamine (DA) vesicle recycling that results in decreased DA release. Increased levels of aSyn in idiopathic PD and sporadic synucleinopathies could be caused by regional dysregulation of aSyn processing or increased levels of aSyn expression. Consequently, strategies that are aimed at decreasing aSyn expression levels or increasing aSyn turnover serve as compelling approaches for new PD drug development (Farrer et al., 2004).

aSyn binds to many synaptosomal proteins that enhance its aggregation (Betzer et al., 2015). Previous studies have described direct protein-protein interactions between aSyn and prolyl oligopeptidase (PREP; also abbreviated "POP" or "PO"; Enzyme Commission number 3.4.21.26) that leads to increase in aSyn aggregation (Brandt et al., 2008; Lambeir, 2011; Savolainen et al., 2015). PREP is a highly conserved serine protease and can be found in the brain and peripheral tissues (Myöhänen et al., 2009). In vitro, PREP has been shown to digest peptides smaller than $3000 \mathrm{Da}$ (Moriyama et al., 1988); nevertheless, in vivo evidence of PREP's role in peptide hydrolysis is inconclusive (Nolte et al., 2009; Tenorio-Laranga et al., 2012). Interestingly, during aging, a robust increase in PREP expression has been detected in mouse brain (Jiang et al., 2001), and in postmortem PD patient brains, where PREP is also colocalized with aSyn (Hannula et al., 2013).

Previously, a possibility to reduce the aSyn aggregation process by small molecule PREP inhibitors in cells and in vivo was shown, raising the pharmacological interest in PREP (Brandt et al., 2008; Myöhänen et al., 2012; Savolainen et al., 2014). Moreover, PREP was identified as a negative regulator of the PI3K class III autophagy pathway, and inhibition of PREP by 4-phenylbutanoyl-l-prolyl2(S)-cyanopyrrolidine (KYP-2047) led to increased autophagosome formation via increased beclin 1 expression levels. Thus, PREP inhibition exerts dual effects on aSyn aggregation, first, by blocking the PREP mediated seeding (Savolainen et al., 2015), and second, by inducing autophagic flux (Savolainen et al., 2014).

Here we have used a mouse PD model with aSyn overexpression based on aSyn delivery by adenoassociated virus (AAV) vectors into $\mathrm{SN}$ to demonstrate that aSyn mediated toxicity and ensuing spontaneous motor imbalance can be reversed after chronic intracranial PREP inhibitor administration. This effect is mediated by a decreased number of aSyn oligomer-specific species, presumably through previously described PREP inhibitor effects on autophagy induction and decrease in aSyn dimerization (Myöhänen et al., 2012; Savolainen et al., 2014, 2015). These data add further evidence of PREP causality in aSyn-modulated neurotoxicity and justifies investigation of PREP inhibitors as potential pharmacological candidates for PD therapy.

\section{Materials and Methods}

Reagents. Reagents used in experiments were purchased from SigmaAldrich if not specified otherwise. Ethanol was purchased from Altia. The
PREP inhibitor KYP-2047 was synthesized at the School of Pharmacy, University of Eastern Finland, as described previously by Jarho et al. (2004). KYP-2047 has been extensively characterized, and its pharmacological and pharmacokinetic profile indicates that KYP-2047 is highly selective, potent, and crosses the blood-brain barrier both in rats and mice (Venäläinen et al., 2006; Jalkanen et al., 2011, 2012, 2014; Myöhänen et al., 2012; Savolainen et al., 2014). AAVs driven by chicken $\beta$-actin promoter (CBA) were acquired from the Michael J. Fox Foundation. AAV2-CBA- $\alpha$-synuclein (AAV-aSyn; $1.5 \times 10^{13} \mathrm{vg} / \mathrm{ml}$ ) and AAV2-CBA-eGFP (enhanced green fluorescent protein; AAV-GFP; $8.1 \times 10^{12} \mathrm{vg} / \mathrm{ml}$ ) were constructed, produced, and titered by the Vector Core at the University of North Carolina (Chapel Hill).

Animals. Male C57BL/6J mice (7-9 weeks old; Envigo) were housed under standard laboratory conditions ( $12 \mathrm{~h}$ light/dark cycle; room temperature, $23 \pm 2^{\circ} \mathrm{C}$; relative humidity, $\left.50 \pm 15 \%\right)$ in individually ventilated cages (Mouse IVC Green Line, Techniplast) with bedding (aspen chips, $5 \times 5 \times 1 \mathrm{~mm}$; $4 \mathrm{HP}$, Tapvei), nesting material (aspen strips; PM90L, Tapvei), and aspen brick $(100 \times 20 \times 20 \mathrm{~mm}$; Tapvei). Mice had access to chow food (Teklad 2016,Envigo) and filtered and irradiated water ad libitum. After surgical procedures, animals were housed individually for the durations of experiment. The experiments were performed according to European Communities Council Directive 86/609/ EEC and were approved by the Finnish National Animal Experiment Board.

Surgical procedures. Mice were anesthetized with isoflurane (4\% induction, $1.5-2.0 \%$ maintenance), and the recombinant AAV vectors were injected above mouse $\mathrm{SN}$ in a stereotaxic operation. The AAV expression pattern and impact on behavior had been tested before PREP inhibition experiment (data not shown). To target the $\mathrm{SN}$, viral vectors were given as single injection (volume, $1 \mu \mathrm{l}$; rate, $0.2 \mu \mathrm{l} / \mathrm{min}$ ) into the left hemisphere, $3.1 \mathrm{~mm}$ anterior and $1.2 \mathrm{~mm}$ lateral to bregma, and $4.2 \mathrm{~mm}$ below the dura [stereotaxic coordinates according to Paxinos and Franklin (1997)]. Osmotic minipump (Alzet 1004, Durect; flow rate of 0.11 $\mu \mathrm{l} / \mathrm{h}$ ) implantation was performed 4 weeks after virus vector injections in a stereotaxic operation. Minipumps were filled with $16 \mathrm{~mm}$ KYP-2047 solution [0.2\% dimethyl sulfoxide (DMSO) in PBS] and primed according to producer's instructions. A cannula (Alzet Brain Infusion Kit 3, Durect) was implanted in the left hemisphere at $0.7 \mathrm{~mm}$ anterior and 1.4 $\mathrm{mm}$ lateral to bregma, and was lowered $2.5 \mathrm{~mm}$ deep to lateral ventricle [stereotaxic coordinates according to Hof et al. (2000)], and the attached osmotic minipump was implanted subcutaneously in the intercapsular region. Buprenorphine was given to relieve postoperative pain. Osmotic minipumps were kept in mice for $28 \mathrm{~d}$ for the groups undergoing behavioral tests, while for verification of PREP enzymatic activity inhibition, osmotic minipumps were kept in mice for $7 \mathrm{~d}$ after surgery.

Animals $(n=36)$ for microdialysis experiments underwent the same set of virus vector microinjections (described above). KYP-2047 chronic treatment was administered for $28 \mathrm{~d}$ with $10 \mathrm{mg} / \mathrm{kg}$ KYP-2047 per day, or vehicle, using osmotic minipumps (Alzet 1002, Durect; flow rate of 0.25 $\mu \mathrm{l} / \mathrm{h}$ ) in the peritoneum as the mouse skull surface is too small to be able to accommodate both the microdialysis probe and cannula. The minipump was replaced after 2 weeks, as the volume was not adequate for a 4 week treatment. The osmotic minipumps were filled with KYP-2047 or vehicle (50\% DMSO) in saline and primed overnight at $37^{\circ} \mathrm{C}$ as described previously (Savolainen et al., 2014). The guide cannula for microdialysis was inserted into striatum at $0.6 \mathrm{~mm}$ anterior and $1.8 \mathrm{~mm}$ lateral, and 2.7 $\mathrm{mm}$ below the dura, 7 weeks after injection of viral vector. The cannula was fastened to the skull with dental cement (Aqualox, Voco) and two stainless-steel screws (DIN84, Helsingin Ruuvihankinta).

Brain homogenization and PREP activity assay. For PREP activity assay, brains were stored at $-80^{\circ} \mathrm{C}$ until dissection. Samples were homogenized in $10 \mathrm{vol}$ of assay buffer $(0.1 \mathrm{M} \mathrm{Na} / \mathrm{K}$ phosphate buffer, $\mathrm{pH} 7.0)$ and centrifuged at $14,000 \times g$ at $4^{\circ} \mathrm{C}$ for $20 \mathrm{~min}$. The supernatants were collected, and $10 \mu \mathrm{l}$ samples were used for the activity assay as described previously (Myöhänen et al., 2008). Briefly, the brain homogenate was preincubated with the assay buffer for $30 \mathrm{~min}$ at $37^{\circ} \mathrm{C}$. Substrate $(4 \mathrm{~mm}$ Suc-Gly-Pro-AMC; Bachem) was added to initiate the reaction, and the incubation continued for $60 \mathrm{~min}$ at $37^{\circ} \mathrm{C}$. The reaction was stopped with $1 \mathrm{~m}$ sodium acetate buffer, $\mathrm{pH}$ 4.2. The formation of 7-amino-4- 
methylcoumarin (AMC; Bachem) was measured using the Wallac 1420 Victor fluorescence plate reader (PerkinElmer). AMC calibration curve standard concentrations were in range from 0.1 to $5 \mathrm{~nm}$ [SCAP], and at these concentrations the curve is linear (for kinetics studies, see to Venäläinen et al., 2002). The excitation and emission wavelengths were 360 and $460 \mathrm{~nm}$, respectively. The protein concentration of the brain homogenate was determined using a BCA protein assay kit (Thermo Fisher Scientific). The velocity of the reaction was calculated as nanomoles AMC per minute per microgram protein.

Behavioral experiment. The cylinder test (height, $15 \mathrm{~cm}$; diameter, 12 $\mathrm{cm}$ ) was used to measure motor asymmetry in spontaneous forelimb use after unilateral microinjections. Baseline paw preference scores were acquired before stereotaxic surgery and every 2 weeks after the surgery. Shortly, each mouse was filmed for $5 \mathrm{~min}$. However, if the number of individual rearing episodes that resulted in the mouse touching the cylinder wall were $<20$, mouse was filmed for an additional $5 \mathrm{~min}$. Data were analyzed by formula, where "both" paws was defined as touches where the animal landed both of the forepaws on the cylinder wall at the same time after the rearing. Nonlesioned control mice should score $\sim 50 \%$ in this test. No habituation of the animals to the testing cylinder was allowed before video recording. One animal from aSyn injected and vehicle treated group was excluded from behavioral analyses for scoring too low in three out of five measurement times $(<10$ touches per record session).

Tissue processing. At 8 weeks after injection, mice intended for immunohistochemistry (IHC) analysis were deeply anesthetized with sodium pentobarbital $(150 \mathrm{mg} / \mathrm{kg})$ and transcardially perfused with PBS followed by $4 \%$ paraformaldehyde (PFA) in PBS. Brains were postfixed for $24-72 \mathrm{~h}$ in $4 \%$ PFA at $4^{\circ} \mathrm{C}$ and transferred to a solution of $10 \%$ sucrose in PBS (pH 7.4; $137 \mathrm{~mm} \mathrm{NaCl}, 2.7 \mathrm{~mm} \mathrm{KCl}, 10 \mathrm{~mm} \mathrm{Na}_{2} \mathrm{HPO}_{4}, 1.8 \mathrm{~mm}$ $\mathrm{KH}_{2} \mathrm{PO}_{4}$ ) overnight at $4^{\circ} \mathrm{C}$. On the next day, tissue was transferred to $30 \%$ sucrose solution in PBS until brains sank. Brains were frozen on dry ice and were kept at $-80^{\circ} \mathrm{C}$ until sectioning. Frozen brain sections were sectioned as $30 \mu \mathrm{m}$ free-floating sections on a cryostat (Leica CM3050) and kept in a cryoprotectant solution (30\% ethylene glycol and 30\% glycerol in $0.5 \mathrm{M}$ phosphate buffer). Mice intended for PREP enzymatic activity assay were transcardially perfused with ice-cold PBS. Thereafter, brains were frozen in isopentene on dry ice and kept at $-80^{\circ} \mathrm{C}$ until further analyses.

Immunohistochemistry. Total aSyn IHC was performed as described by Myöhänen et al. (2012). In brief, the endogenous peroxidase activity was inactivated with $10 \%$ methanol and $3 \%$ hydrogen peroxide $\left(\mathrm{H}_{2} \mathrm{O}_{2}\right)$ solution in PBS, pH 7.4, for $10 \mathrm{~min}$, and nonspecific binding was blocked with $10 \%$ normal donkey serum (catalog \#S30, Millipore) in PBS containing $0.5 \%$ Triton $\mathrm{X}-100$. The sections were incubated overnight at room temperature with sheep anti-aSyn antibody (1:500 dilution in 1\% normal donkey serum in PBS containing $0.5 \%$ Triton X-100; ab6162, RRID:AB_2192805, Abcam), followed by washing with PBS containing $0.5 \%$ Triton X-100. The sections were then incubated with donkey antisheep HRP-conjugated secondary antibody for $2 \mathrm{~h}$ (1:500 dilution in $1 \%$ normal serum in PBS containing $0.5 \%$ Triton X-100; ab6900, RRID: AB_955452, Abcam). The antigen-antibody complexes were identified following incubation with $0.05 \% 3,3^{\prime}$-diaminobenzidine (DAB) and $0.03 \% \mathrm{H}_{2} \mathrm{O}_{2}$ solution. Finally, the sections were transferred to glass slides, dehydrated in alcohol series, and mounted with Depex (BDH).

Tyrosine hydroxylase (TH) IHC was modified from the study by Mijatovic et al. (2007). In short, after blocking endogenous peroxidase activity (as above) the sections were incubated for $30 \mathrm{~min}$ in $10 \%$ normal goat serum to block nonspecific binding, after which the sections were incubated overnight in rabbit anti-TH primary antibody (1:2000; AB152, RRID:AB_390204, Millipore). Subsequently, the sections were placed in goat anti-rabbit biotin-conjugated secondary antibodies (1:500; BA1000, RRID:AB_2313606, Vector Laboratories). The signal was enhanced with the avidin-biotin complex method (Standard Vectastain ABC kit, RRID: AB_2336819, Vector Laboratories) and visualized with DAB.

Oligomer-specific $\alpha$-synuclein IHC was performed using the Basic Vector Mouse on Mouse (M.O.M.) Immunodetection Kit (BMK-2202, RRID:AB_2336833, Vector Laboratories) with an adapted protocol for mouse primary antibodies on mouse tissue (Brännström et al., 2014). In short, after blocking endogenous peroxidase activity (as above), the sections were incubated for $30 \mathrm{~min}$ in M.O.M. Mouse Ig Blocking Reagent to block nonspecific binding and $5 \mathrm{~min}$ in M.O.M. diluent, and transferred overnight in mouse anti-human $\alpha$ synuclein oligomer-specific primary antibody (1:200 in M.O.M. diluent; AS132718, RRID: AB_2629502, Agrisera). The sections were then incubated with goat antimouse HRP-conjugated secondary antibody (dilution, 1:300 in M.O.M. diluent, catalog \#31430, RRID:AB_228307, Thermo Fisher Scientific) and visualized with DAB.

Proteinase K treatment. The proteinase K (PK) protocol was adapted from the study by Chu and Kordower (2007), with alteration in PK incubation time for rodent brains suggested by Angot et al. (2012). Shortly, sections containing $\mathrm{SN}$ and striatum were mounted onto gelatin-coated slides and dried overnight at $55^{\circ} \mathrm{C}$. Sections were wetted with TBS-T and digested with $10 \mu \mathrm{g} / \mathrm{ml} \mathrm{PK}$ (\#V3021, Promega) in TBS-T for $10 \mathrm{~min}$ at $55^{\circ} \mathrm{C}$. The sections were postfixed with $4 \%$ PFA for $10 \mathrm{~min}$ and processed for total aSyn or aSyn oligomer-specific immunostaining with the same primary and secondary antibody concentrations as described above.

Microscopy and stereology. The optical densities (ODs) of TH, aSyn, and oligomer-specific aSyn from ipsilateral and contralateral striatum and $\mathrm{SN}$ were determined. Digital images were scanned at $40 \times$ magnification with a Pannoramic Flash II Scanner (3DHISTECH), and three coronal sections from each mouse were processed for further analyses with Pannoramic Viewer (version 1.15.3. RRID:SCR_014424, 3DHISTECH). Images were converted to grayscale and inverted, and line analysis tools for striatum or freehand for SN in ImageJ (1.48b; RRID:SCR_003070, NIH) was used to measure the OD of immunoreactivity. To correct the effect of TH background staining, correction values were obtained from the corpus callosum of each section and subtracted from the OD values of the striatum. The data are presented as percentages of the intact side.

The number of tyrosine hydroxylase-positive $(\mathrm{TH}+)$ cells in $\mathrm{SN}$ pars compacta ( $\mathrm{SNpc}$ ) was estimated using the optical fractionator method in combination with the dissector principle and unbiased counting rules (Gundersen et al., 1999). The SNpc was analyzed with a Stereo Investigator platform (RRID:SCR_002526, MicroBrightField) attached to an Olympus BX51 microscope. From each animal, three sections from the central portion of the SNpc were selected for quantitative analysis. Each reference space was outlined at low magnification $(4 \times)$, and cells were counted using a high-magnification $(60 \times$ UPlanApo, 1.4 numerical aperture, oil immersion) objective. The grid size was $100 \times 80 \mu \mathrm{m}$, and the counting frames were $60 \times 60 \mu \mathrm{m}$. Injected and noninjected SNpc (internal control) was counted, no cell loss was observed in the noninjected side. The coefficient of error, calculated according to the procedure of Schmitz and Hof (2005), was between 0.05 and 0.10. Results are expressed as the mean cell number per section; all stereological estimations were blinded.

The number of aSyn oligomer-specific particles in SN was estimated using the optical fractionator method in combination with the dissector principle and unbiased counting rules (Gundersen et al., 1999). From each animal, four sections from the central portion of the SN were selected for quantitative analysis. Only mouse brains that were injected with aSyn virus vector were counted since no aSyn oligomer staining was seen in GFP control brains (see Fig. 4B). Each reference space was outlined at low power $(4 \times)$, and particles were counted using a highmagnification $(60 \times$, oil immersion) objective. Grid size was $120 \times 120$ $\mu \mathrm{m}$, and the counting frames were $60 \times 60 \mu \mathrm{m}$ large. The average coefficient of error for each region was in range of 0.05 to 0.1 . Results were expressed as the mean cell number per section, and all stereological estimations were blinded.

Pannoramic Viewer (version 1.15.3. 3DHISTECH) was used for acquisition of low-magnification images. High-magnification images were acquired with a QImaging 2000R camera attached to an Olympus BX51 microscope with an Olympus UPlanApo $20 \times / 0.5,100 \times / 1.35$ oil iris microscope objective lens and processed with Adobe Photoshop CS6 (version $13.0 \times 64$, RRID:SCR_014199).

Microdialysis. Microdialysis was performed after 28 d of KYP-2047 or vehicle treatment. A microdialysis probe (1 mm cuprophan membrane; outer diameter, $0.2 \mathrm{~mm}$; $6 \mathrm{kDa}$ cutoff; AT4.9.1.Cu, AgnTho's) was in- 
intraventricular

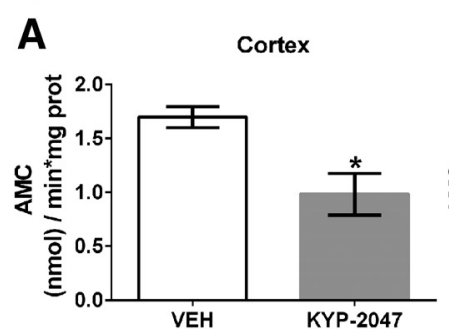

B

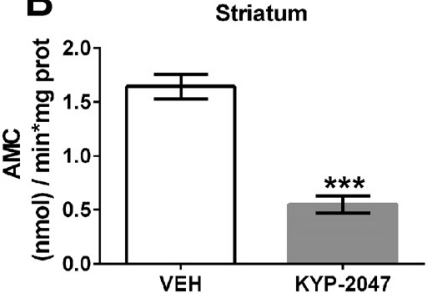

intraperitoneal

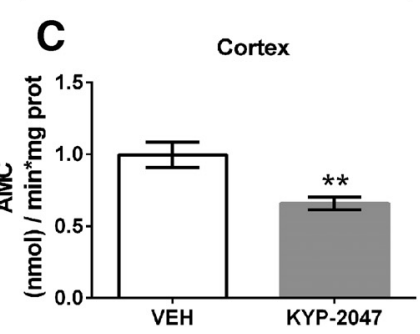

Figure 1. The effect of KYP-2047 on mouse brain PREP activity. A-C, KYP-2047 intraventricular administration significantly reduced PREP activity in mouse striatum and cortex 1 week after osmotic minipump implantation $(\boldsymbol{A}, \boldsymbol{B})$, and PREP inhibition was observed after 4 week intraperitoneal KYP-2047 administration in mouse cortex ( $\boldsymbol{C}$ ) compared to vehicle administration. IntraventricularVEH, $n=3$; intraventricular KYP-2047, $n=5$; intraperitoneal VEH, $n=23$; intraperitoneal KYP-2047, $n=21)$. Error bars represent means \pm SEM. ${ }^{*} p<0.05$; ${ }^{* *}<0.01$; ${ }^{* * *} p<$ 0.001 (unpaired Student's $t$ test).

serted into the guide cannula $2 \mathrm{~h}$ before the experiment, and the probe was perfused with a modified Ringer's solution [containing (in mM) 147 $\mathrm{NaCl}, 1.2 \mathrm{CaCl}_{2}, 2.7 \mathrm{KCl}, 1.0 \mathrm{MgCl}_{2}, 0.04$ ascorbic acid] at the flow rate of $2.0 \mu \mathrm{l} / \mathrm{min}$. Samples were collected for $3 \mathrm{~h}(9 \times 20 \mathrm{~min}, 40 \mu \mathrm{l} / \mathrm{sample})$ for high-performance liquid chromatography (HPLC) analysis. Mice were killed right after the microdialysis experiment by cervical dislocation and decapitation. The brains were removed and rapidly frozen in isopentane on dry ice. The concentrations of DA, its metabolites dihydroxyphenylacetic acid (DOPAC) and homovanillic acid (HVA), and 5-hydroxyindoleacetic acid (5-HIAA) were measured by HPLC with electrochemical detection as described previously (Käenmäki et al., 2010), with slight modifications, and the concentration of GABA was measured by HPLC with fluorescence detection as described previously (Vihavainen et al., 2008), with slight modifications.

The HPLC system for the determination of extracellular concentrations of DA, its metabolites, and 5-HIAA consisted of a solvent delivery pump (model PU-2080 Plus, Jasco), a pulse damper (SSI LP-21, Scientific Systems), an autosampler (SIL-20AC Autosampler, Shimadzu), an analytical column (Kinetex C-18, $5 \mu \mathrm{m}, 4.60 \times 50 \mathrm{~mm}$, Phemomenex) thermostated by a column heater (CROCO CIL, Cluzeau Info-Labo; LaChrom L-7350, Merck), an electrochemical detector (Coulochem II detector, ESA Biosciences), and a model 5014B microdialysis cell (ESA Biosciences). The mobile phase consisted of $0.1 \mathrm{M} \mathrm{NaH}_{2} \mathrm{PO}_{4}$ buffer (Merck), $8 \%$ (v/v) methanol (Merck), $0.2 \mathrm{M}$ ethylenediaminetetraacetic acid, and $100 \mathrm{mg} / \mathrm{L}$ octanesulfonic acid, $\mathrm{pH} 4.0$, and the flow rate was $1.0 \mathrm{ml} / \mathrm{min}$. DA was reduced with an amperometric detector (potential $-120 \mathrm{mV}$ against an $\mathrm{Ag} / \mathrm{AgCl}$ reference electrode) after being oxidized with a coulometric detector $(+300 \mathrm{mV})$; DOPAC and HVA were oxidized with the coulometric detector. The sample injection volume was $20 \mu \mathrm{l}$, and the column temperature was kept at $40^{\circ} \mathrm{C}$. The chromatograms were processed by AZUR chromatography data system software (Cromatek).

The HPLC system for determination of the extracellular concentration of GABA consisted of a solvent delivery pump (model PU-1580 HPLC Pump, Jasco) connected to an online degasser (3-Line Degasser, DG980-50, Jasco) and a ternary gradient unit (LG-1580-02, Jasco), a refrigerated autosampler (NexeraX2 SIL-30AC Autosampler, Shimadzu), an analytical column (Kinetex C-18, $5 \mu \mathrm{m}, 4.60 \times 50 \mathrm{~mm}$, Phemomenex) protected by a $0.5 \mathrm{~mm}$ inlet filter and thermostated by a column heater (CROCO CIL, Cluzeau Info-Labo), and a fluorescence detector (model FP-1520 Intelligent Fluorescence Detector, Jasco). The wavelengths of the fluorescence detector were set to $330 \mathrm{~nm}$ (excitation) and $450 \mathrm{~nm}$ (emission). The mobile phase consisted of $0.1 \mathrm{M} \mathrm{NaH}_{2} \mathrm{PO}_{4}$ buffer (Merck), pH 4.9 (adjusted with $\mathrm{Na}_{2} \mathrm{HPO}_{4}$ ), 20\% (v/v) acetonitrile (Merck), and the flow rate was $1.2 \mathrm{ml} / \mathrm{min}$. Automated sample derivatization was performed using the autosampler at $8^{\circ} \mathrm{C}$. The autosampler was programmed to add $6 \mu$ of the derivatizing reagent ( $3 \mu$ lof mercaptoethanol, $1 \mathrm{ml}$ of o-phthaldialdehyde) to $15 \mu \mathrm{l}$ of a microdialysis sample, to mix two times, and to inject $20 \mu$ lonto the column after a reaction time of $1 \mathrm{~min}$. The chromatograms were processed by AZUR chromatography data system software (Cromatek).

HPLC tissue analysis. Striatal tissue samples were punched below the corpus callosum $+0.74 \mathrm{~mm}$ from bregma by using sample corer (inner diameter, $2 \mathrm{~mm}$ ) with a plunger (Stoelting) on a cryostat (Leica CM3050), and samples from SN were punched $-2.8 \mathrm{~mm}$ from bregma by using sample corer (inner diameter, $1 \mathrm{~mm}$ ) with a plunger (Stoelting). The concentrations of DA, its metabolites DOPAC and HVA, and 5-HIAA in tissue samples of striatum and SN were analyzed with a HPLC equipped with an electrochemical detector as described previously (Airavaara et al., 2006). The tissue concentrations of GABA and glutamate were analyzed with HPLC equipped with a fluorescence detector. Injection volume was $10 \mu \mathrm{l}$, and the mobile phase consisted of $15 \%(\mathrm{v} / \mathrm{v})$ acetonitrile in glutamate. Otherwise the method was similar to GABA analysis of microdialysis samples (described above). Concentrations were calculated as nanograms per milligram of brain tissue.

Statistical analyses. Statistical analyses were performed using either GraphPad Prism (version 6.02, RRID:SCR_002798) or SPSS Statistics (version 22.0.0.1, RRID:SCR_002865, IBM) tools. The statistical tests used were one- and two-way ANOVAs with Tukey's post hoc comparison and Student's $t$ test. Data are presented as mean \pm SEM, and differences were considered statistically significant at $p<0.05$.

\section{Results}

\section{PREP activity in vivo}

PREP activity was measured after 1 week of osmotic minipump implantation to verify the proper placement of the osmotic minipumps, as PREP enzymatic activity cannot be verified from PFA-perfused animal tissue. In this study, PREP inhibition in cortex samples was $\sim 50 \%$ (Fig. $1 A$ ), and in striatum $\sim 70 \%$ (Fig. 1B). PREP enzymatic activity (nanomoles AMC per minute per microgram protein) was significantly different in cortex samples for vehicle-treated (mean, 1.696; SD, 0.1673) and KYP-2047treated animals (mean, $0.9834 ; \mathrm{SD}, 0.4345 ; t_{(6)}=2.654, p=$ 0.0378 , unpaired Student's $t$ test). Higher PREP inhibition levels were observed in striatum than in cortex for vehicle-treated animals (mean, 1.644; SD, 0.1985) and KYP-2047-treated animals (mean, 0.5524; SD, 0.1649; $t_{(5)}=7.978, p=0.0005$, unpaired Student's $t$ test). KYP-2047 has been shown to remain stable in osmotic minipumps for 1 month with $~ 50 \%$ inhibition of PREP activity (Savolainen et al., 2014). PREP activity for HPLC and microdialysis studies were verified after tissue collection (week 8 ), with PREP activity significantly different between vehicletreated (mean, 0.9960; SD, 0.08805) and KYP-2047-treated animals (mean, 0.6590; SD, 0.04474; $t_{(42)}=3.316, p=0.0019$, unpaired Student's $t$ test; Fig. $1 C$ ).

\section{KYP-2047 restores aSyn-induced behavioral deficits in the cylinder test}

In the cylinder test, animals with nigrostriatal overexpression of aSyn showed a significantly reduced use of the forepaw contralateral to the injected hemisphere, and a statistically significant difference between aSyn and GFP groups was seen at weeks 2 and 4 


\section{Cylinder test}

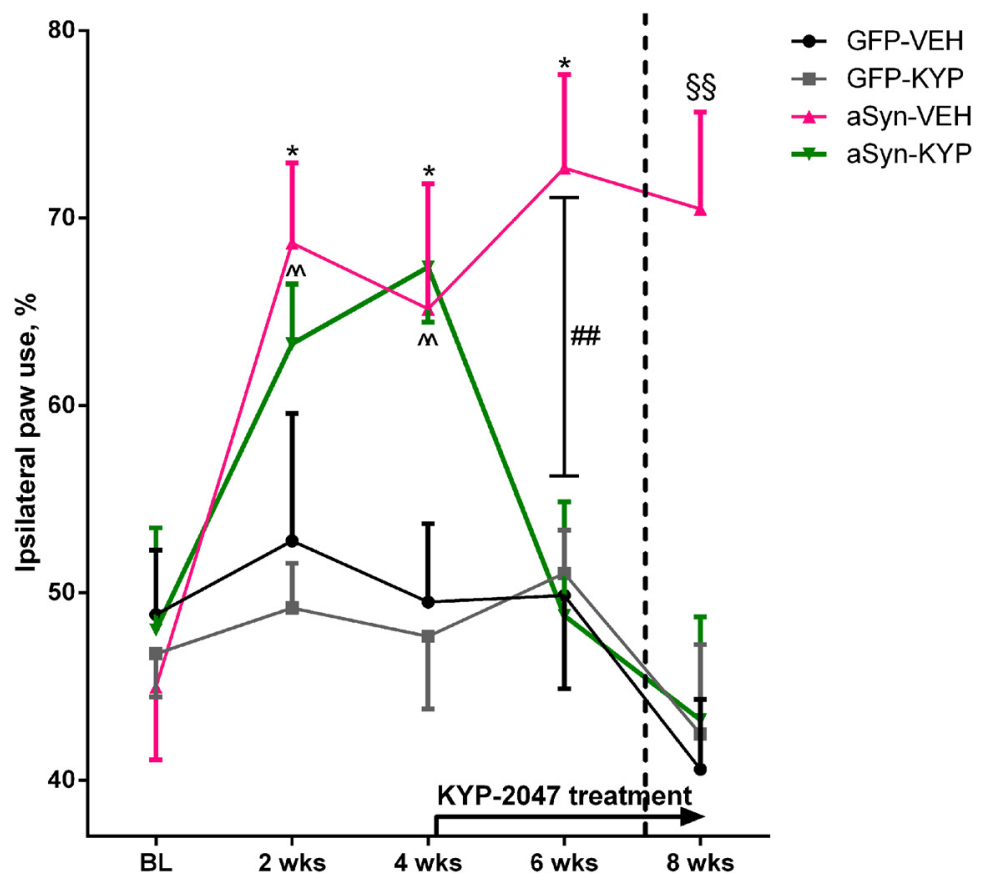

Figure 2. Unilateral AAV-aSyn virus vector-injected mouse on the cylinder test. Unilateral AAV-aSyn virus vector injection above mouse SN caused increased ipsilateral paw use starting 2 weeks after injection [aSyn-VEH, 0.2\% DMSO; aSyn-KYP-2047, 16 $\mathrm{mm}$ ), while AAV-GFP injection did not cause any changes in paw use. Chronic KYP-2047 administration (aSyn-KYP) started 4 weeks after injection rescued spontaneous forepaw, while vehicle treatment (aSyn-VEH) had no effect. The dashed line separates the numbers of animals per group (left, $n=7-9$; right, $n=4-7$ ). Error bars represent means \pm SEM. ${ }^{*} p<0.05$, aSyn-VEH versus GFP-VEH; ${ }^{\wedge} p<0.01$, aSyn-KYP versus GFP-KYP; ${ }^{\# \#} p<0.01$, aSyn-VEH versus aSyn-KYP; ${ }^{\S \S} p<0.01$, aSyn-VEH versus aSynKYP, GFP-VEH, and GFP-KYP (two-way ANOVA with Tukey's post hoc comparison).

after injection $\left[F_{(1,31)}=16,873, p=0.000271\right.$, repeatedmeasures two-way ANOVA; $p<0.05$ for aSyn vehicle-treated (aSyn-VEH) or KYP-2047-treated (aSyn-KYP) vs GFP-VEH animals; $p<0.01$ for aSyn-VEH or aSyn-KYP vs GFP-KYP animals; Tukey's post hoc test). After osmotic minipump implantation, when behavioral deficit was seen (week 4), the significant difference in the paw use was lost in 2 weeks (week 6) between GFP groups and the aSyn-KYP group, but significance was retained between GFP groups and aSyn-VEH animals (main effect for treatment, $F_{(1,29)}=5.575, p=0.025$; combined treatment by virus $F$ ratio, $F_{(1,29)}=6.802, p=0.014$, repeated-measures twoway ANOVAs; difference between GFP groups and aSyn-VEH animals, $p<0.05$, Tukey's post hoc test). Importantly, at the 6 week time point, aSyn-VEH and aSyn-KYP groups had a significant difference ( $p=0.006$, Tukey's post hoc test) in their paw use, pointing to decreased toxic impact of aSyn on the nigrostriatal system after KYP-2047 treatment compared to week 4 after injections.

After aSyn virus vector injection, we observed motor asymmetry in spontaneous behavior characterized by the cylinder test, which developed over a period of 2 months following virus injections. In Figure 2, we present an 8 week time period (with 4 weeks of KYP-2047 treatment). Statistical analyses for the 8 week time point were performed with a reduced number of animals $(n=4-7)$. Nevertheless, the KYP-2047 effect extended past the 6 week time point for the remaining animals (main effect for virus, $F_{(1,17)}=10.539, p=0.005$; treatment, $F_{(1,17)}=5.048, p=0.038$; combined treatment by virus $F$ ratio, $F_{(1,17)}=4.521, p=0.048$, repeated-measures two-way ANOVAs; difference between GFP groups and aSyn-VEH an- imals, aSyn-KYP vs aSyn-VEH animals, $p<0.01$, Tukey's post hoc test; Fig. 2, right of the dashed line).

Before these experiments, virus vector characterization was done for 4 months both for behavioral changes and IHC as virus vector characterization (see Materials and Methods) was described previously in rats (Kirik et al., 2002; Kirik and Björklund, 2003). Four weeks postinjection was selected as a time window for minipump implantations as at the 4 week point behavioral deficits were fully developed in preliminary testing (our unpublished observation).

\section{Optical density of total aSyn staining in} striatum, $\mathrm{SNpc}$, and substantia nigra pars reticulata

OD analyses revealed significant differences in total aSyn immunoreactivity in striatum between aSyn- and GFP-injected animals (Fig. 3B; $F_{(3,30)}=19.12, p<$ 0.0001 , one-way ANOVA with Tukey's post hoc comparison). The total aSyn distribution pattern was similar in vehicleand KYP-2047-treated animal groups. Similar correlation was observed in SNpc and substantia nigra pars reticulata (SNpr) between GFP- and aSyn-injected animals [Fig. $3 C, D$; $\mathrm{SNpc}, F_{(3,30)}=44.66$, $p<0.0001 ; \mathrm{SNpr}, F_{(3,30)}=20.72, p<$ 0.0001 ; one-way ANOVA with Tukey's post hoc comparison with $F$ ratio $F_{(3,30)}=44.66, p<0.0001$ (Fig. $3 C$ )] and in SNpr between GFP-VEH (mean, 101.3\%; SD, 1.245), GFP-KYP (mean, 101.1; SD, 1.801), aSyn-VEH (mean, 150.2; SD, $24.76)$, and aSyn-KYP (mean, $140.1 ; \mathrm{SD}, 19.87)$ groups $\left(F_{(3,30)}=\right.$ $20.72, p<0.0001$; Fig. $3 D$ ). Similar to striatum, there were no differences between vehicle- and KYP-2047-treated groups.

\section{aSyn oligomer-specific staining distribution in $\mathrm{SN}$ is} decreased after KYP-2047 administration

To determine whether KYP-2047 decreases the amount of aSyn oligomers, as shown previously by Myöhänen et al. (2012), Dokleja et al. (2014), and Savolainen et al. (2014), an oligomerspecific aSyn staining was performed (Fig. 4B-D). KYP-2047 caused a significant decrease in the number of aSyn oligomerspecific particles (mean, 11,388; SD, 4144) compared to vehicle (mean, 28,055; SD, 8549) treatment in the groups that, before drug treatment, received AAV-aSyn injection (Fig. 4A, C,D; $p<$ 0.0001 vehicle vs KYP-2047, Student's $t$ test), while aSyn oligomer-specific staining was not detected in AAV-GFPinjected controls (Fig. 4B). In addition, no statistical differences were observed in OD of oligomer-specific staining in striatum (data not shown).

\section{aSyn virus vector injection produces proteinase $K$ treatment-resistant aSyn oligomers}

PK treatment was used to verify PK-resistant aSyn oligomer species. After the PK treatment, we saw reduced diffuse staining in total aSyn, indicating increased PK-resistant forms of aSyn (Fig. $4 G, I)$. PK treatment also dissolved part of the aSyn oligomerspecific staining, particularly smaller particles (Fig. $4 K, M$ ), but 
A
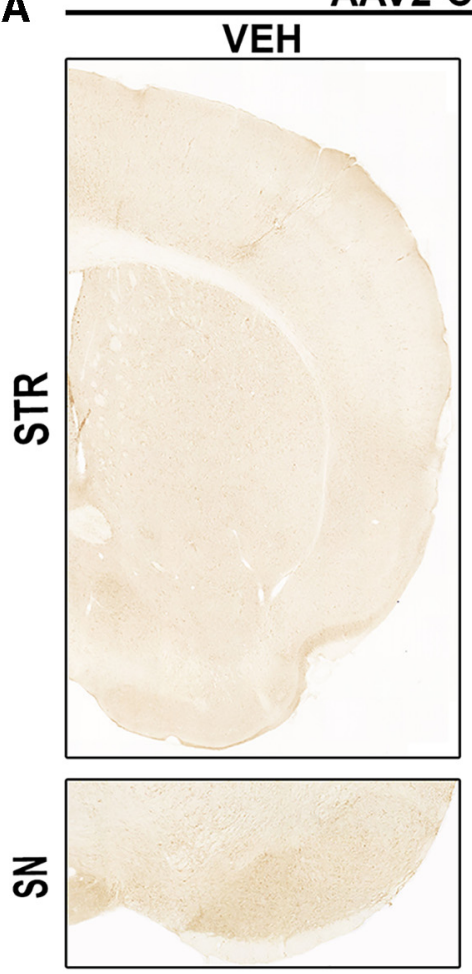

B

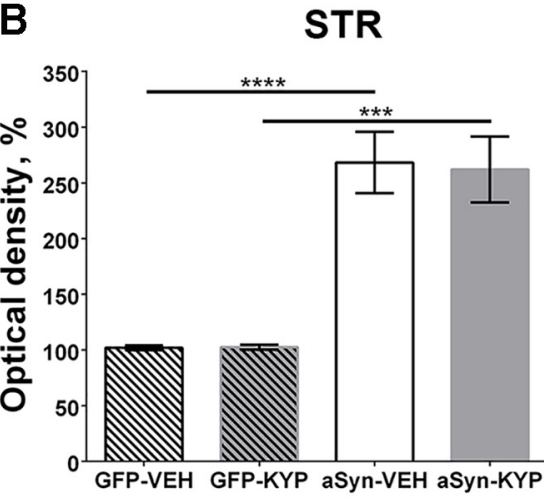

KYP-2047
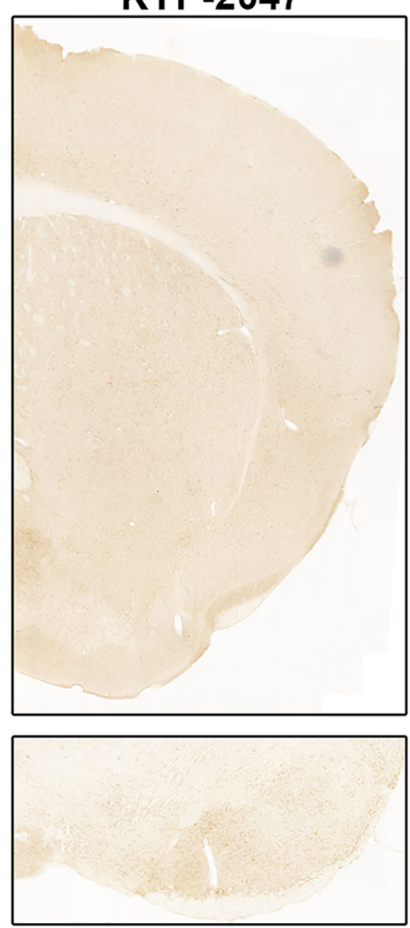
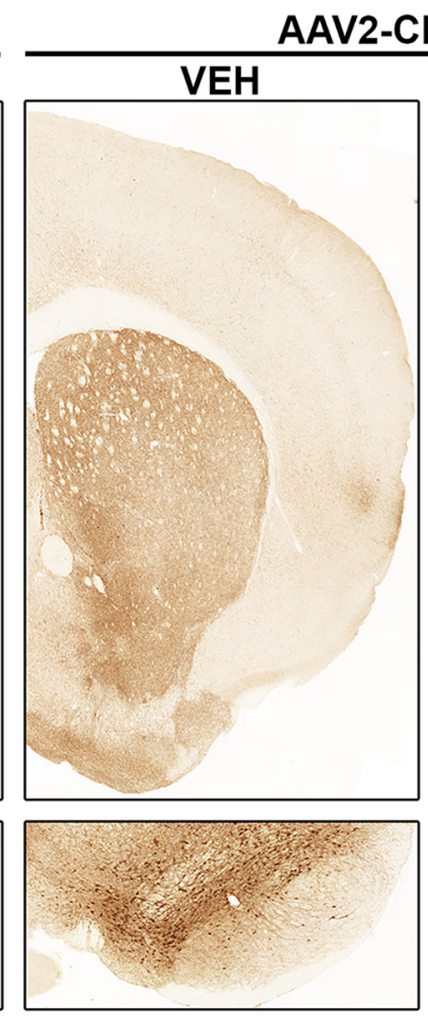

C

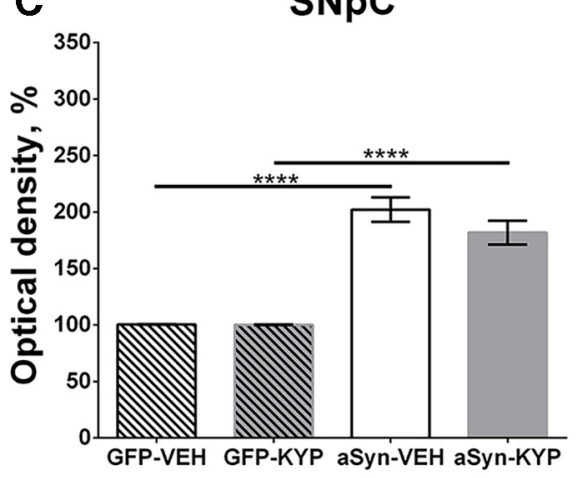

D

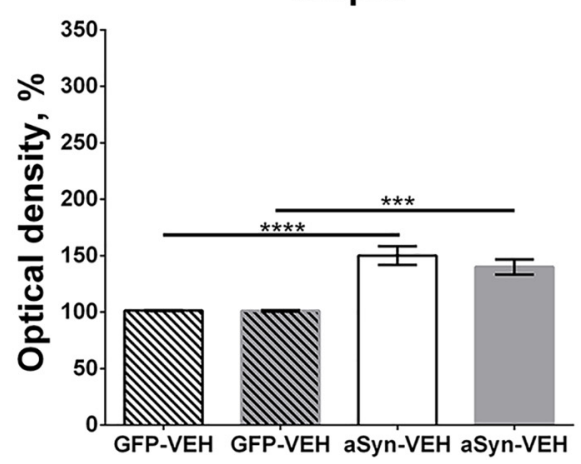

Figure 3. Total aSyn immunoreactivity in striatum (STR) and SN after AAV-GFP and AAV-aSyn injections. $A$, aSyn immunoreactivity showed a robust increase 8 weeks after unilateral AAV-aSyn injection but not in AAV-GFP control groups (GFP-VEH and GFP-KYP). $\boldsymbol{B}-\boldsymbol{D}$, Significant increase in total aSyn OD was observed in STR, SNpc, and SNpr in OD analyses of AAV-aSyn-injected brain. KYP-2047 treatment (aSyn-KYP) did not have an effect on total aSyn amounts $(\boldsymbol{A}-\boldsymbol{D})$. OD of total aSyn staining is shown as a fraction of the control side. $n=7-9$ in each group. Error bars represent means \pm SEM. ${ }^{* * *} p<0.001 ;{ }^{* * *} p<0.0001$ (one-way ANOVA with Tukey's post hoc comparison).

revealed intracellular PK-resistant particles (Fig. $4 K, M$ ). Sections with KYP-2047 treatment had visually less bright inclusions and staining in general (Fig. $4 H, I, L-M)$, and aSyn distribution in SNpr was less pronounced (Fig. $4 H, I, L-M$ ).

To investigate in detail the effect that PK treatment had on aSyn oligomer-specific particle count, the stereological method was applied for vehicle- or KYP-2047-treated AAV-aSyn-injected brains. The number of aSyn oligomer-specific particles in the KYP-2047-treated group (mean, 1251; SD, 529) compared to the vehicle-treated group (mean, 1884; SD, 566) was not statistically significant (Fig. $4 E, K, M ; p=0.0736$ vehicle vs KYP-2047, Student's $t$ test). Nevertheless, the aSyn oligomer-specific particle count in Figure $4 E$ presents an $\sim 10$-fold decrease in aSyn oligomer-specific particle numbers after PK treatment as opposed to PK-nontreated aSyn oligomer-specific particle numbers (Fig. 4A).
aSyn virus vector causes mild loss for nigrostriatal tyrosine hydroxylase

To study whether 8 week overexpression of aSyn causes DAergic neuron loss in mice, we identified TH+ neurons in SNpc and their fibers in striatum by IHC (Fig. 5A-D). Although the effect of aSyn overexpression was mild for striatal TH, OD analyses revealed significant differences in the OD of the TH immunoreactivity in striatum, where the most significant decrease was seen in the vehicle-treated aSyn-injected group compared to GFP-VEH control group (Fig. $3 A, C ; F_{(3,29)}=4.229 ; p=0.0135$, one-way ANOVA; $p<0.05$, aSyn-VEH vs GFP-VEH, Tukey's post hoc test). More pronounced differences were seen in SNpc (Fig. $5 A, D)$, where the vehicle-treated aSyn group was significantly different from both GFP groups $\left(F_{(3,30)}=7.366 ; p=0.0008\right.$, one-way ANOVA; $p<0.01$, aSyn-VEH vs GFP-VEH and GFPKYP, Tukey's post hoc test). Interestingly, no statistical difference 


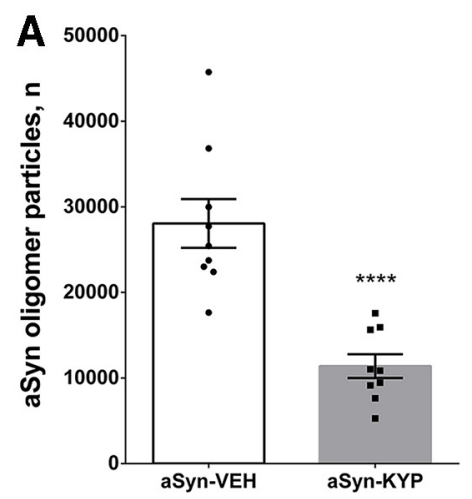

B C D
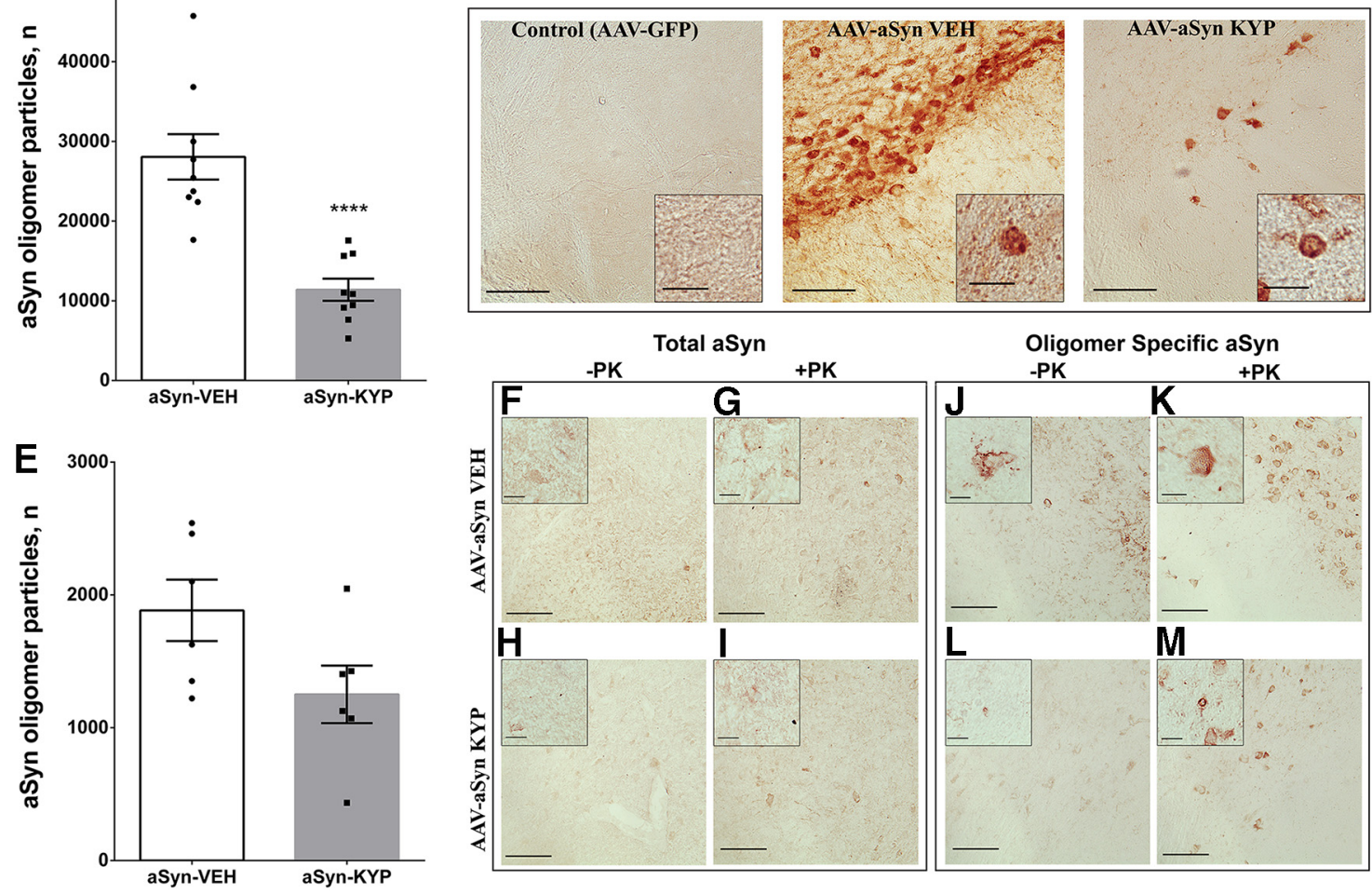

Figure 4. aSyn oligomer immunoreactivity 8 weeks postinjection in AAV-aSyn-injected mouse SN. A, aSyn oligomer-specific particle stereological count was decreased in AAV-aSyn-injected SN after chronic KYP-2047 administration (aSyn-KYP) compared to vehicle treatment (aSyn-VEH). B, No aSyn oligomer staining was observed in AAV-GFP-injected animal SN. C, D, Robust immunostaining of aSyn oligomers was seen in the SNs of vehicle-treated AAV-aSyn-injected animals, while KYP-2047 clearly reduced aSyn oligomer-stained particles ( $n=9$ in both groups). $\boldsymbol{E}$, aSyn oligomer-specific particle stereological count after PK treatment did not show significant differences between AAV-aSyn-injected SN after either chronic KYP-2047 administration (aSyn-KYP) or vehicle treatment (aSyn-VEH). $\mathbf{G}, \boldsymbol{I}, \boldsymbol{K}, \boldsymbol{M}$, PK treatment (+PK) only partially cleared total aSyn $(\boldsymbol{G}, \boldsymbol{I})$ and oligomer-specific aSyn staining $(\boldsymbol{K}, \boldsymbol{M})$ in AAV-aSyn-treated mouse SN. $\boldsymbol{F}-\boldsymbol{I}$, Total aSyn staining shows reduced staining after + PK $(\boldsymbol{G}, \boldsymbol{I})$ compared to staining without proteinase $\mathrm{K}(-\mathrm{PK} ; \boldsymbol{F}, \boldsymbol{H})$. J-M, A similar effect by PK is seen in oligomer-specific aSyn staining. Less PK-resistant staining, particularly in oligomeric immunohistochemistry, is visually seen in KYP-2047-treated brains $(\boldsymbol{I}, \boldsymbol{M})$. Error bars represent means \pm SEM. ${ }^{* * *} p<0.0001$ (unpaired Student's $t$ test). Scale bars: $100 \mu \mathrm{m}$; insets, $15 \mu \mathrm{m}$.

was observed for the aSyn-KYP group compared to GFP control groups in striatum or $\mathrm{SN}$.

To investigate this issue in a more quantitative way, we applied the stereological counting method for $\mathrm{TH}+$ neuron estimation in injected and uninjected hemispheres of SNpc (Fig. 5B). One-way ANOVAs did not reveal statistical significance between the groups $\left(F_{(3,28)}=2.784, p=0.0593\right)$. However there was mild $\mathrm{TH}+$ cell loss, particularly in the vehicle-treated aSyn group (mean, 82.57; SD, 10.53). This is in accordance with preliminary observations by our group and other groups (Dong et al., 2002; St Martin et al., 2007) and might highlight that longer expression times are required for $\mathrm{TH}+$ cell loss in SNpc (Kirik et al., 2002). Indeed, our results from preliminary studies showed that $\mathrm{TH}+$ OD is decreased by $30 \%$ in striatum and 50\% in SNpc 16 weeks after AAV-aSyn vector injections compared to AAV-GFPinjected animals (data not shown).

AAV-aSyn decreases extracellular DA and its metabolites and tissue DA in the nigrostriatal pathway

Overexpression of aSyn significantly decreased the extracellular levels of the main metabolites of DA, DOPAC and HVA, in striatum (Fig. $6 B ; F_{(1,35)}=4.164, p=0.049$, two-way ANOVA), and there was a similar trend in DA (Fig. $6 A ; F_{(1,35)}=3.758, p=$ 0.061 , two-way ANOVA) in the microdialysis study. Extracellular concentration of GABA was not changed significantly (Fig. 6D; $F_{(1,32)}=1.786, p=0.191$, two-way ANOVA), but as a GABA reuptake inhibitor was not used, the method was probably not sensitive enough to detect changes in GABA. Overexpression of aSyn also decreased DA in striatal tissue (Fig. $7 A ; F_{(1,41)}=13.049$, $p=0.001$, two-way ANOVA) and the metabolites of DA in nigral tissue (Fig. $7 H ; F_{(1,41)}=6.502, p=0.015$, two-way ANOVA). There was a similar trend in the metabolites of DA in striatal tissue (Fig. $7 B ; F_{(1,41)}=3.611, p=0.064$, two-way ANOVA), but the concentration of DA was not changed in nigral tissue (Fig. $7 G)$. Additionally, serotonin (5-HT) was decreased in nigral tissue (Fig. 7I; $F_{(1,41)}=6.219, p=0.017$, two-way ANOVA), and there was a similar trend in the main metabolite of 5-HT in striatal tissue (Fig. $7 D ; F_{(1,41)}=3.731, p=0.060$, two-way ANOVA). Concentrations of GABA and glutamate were unchanged in both striatum and SN (Figs. 6D, $7 E, F, K, L$ ). KYP-2047 treatment had a beneficial trend particularly on extracellular DA (Fig. 6A), but it did not reach statistical significance for extracellular concentration or tissue concentration of DA, 5-HT, their metabolites, glutamate, or GABA, although it had a neuroprotective effect on $\mathrm{TH}+$ neurons and behavior.

\section{Discussion}

In this study, inhibition of PREP by a small molecule inhibitor, KYP-2047, in a virus vector-based unilateral aSyn overexpression mouse model, restored the behavioral deficit by reducing aSyn oligomer-specific immunoreactivity and protecting $\mathrm{TH}+$ neurons in the SN. Notably, KYP-2047 treatment was started postsymptomatically, when behavioral deficit was already seen in the cylinder test. To our knowledge, this is the first time a behav- 
A
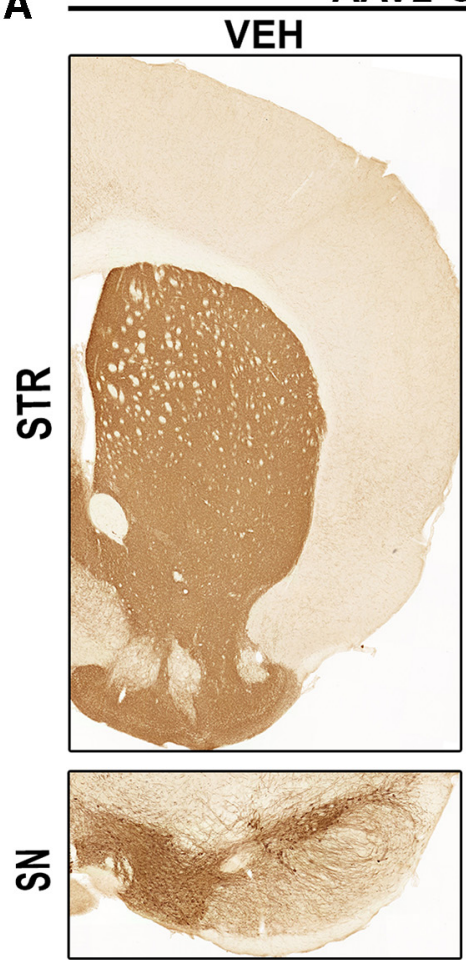

B

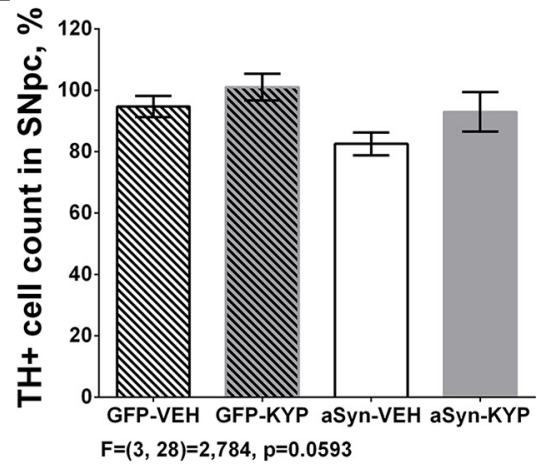

AAV2-CBA-aSyn
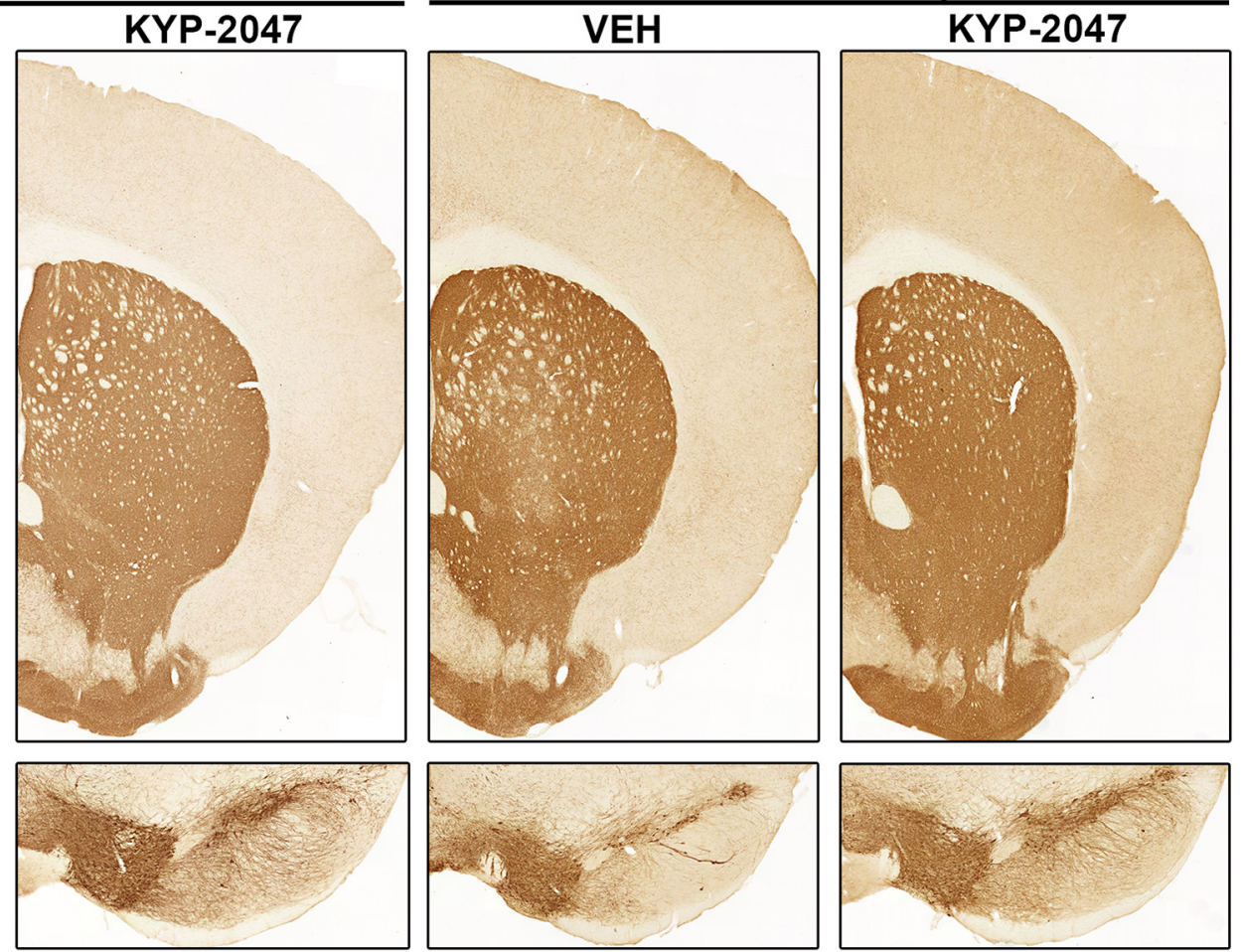

C

STR

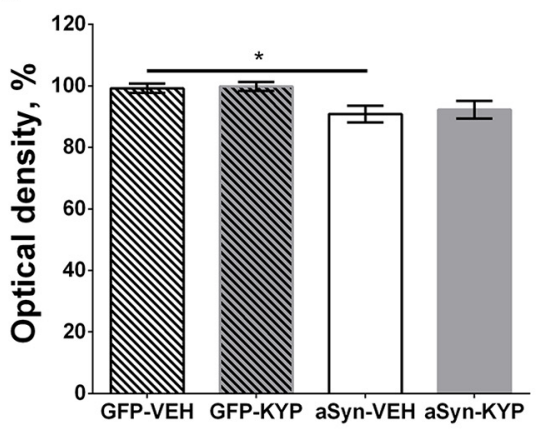

D

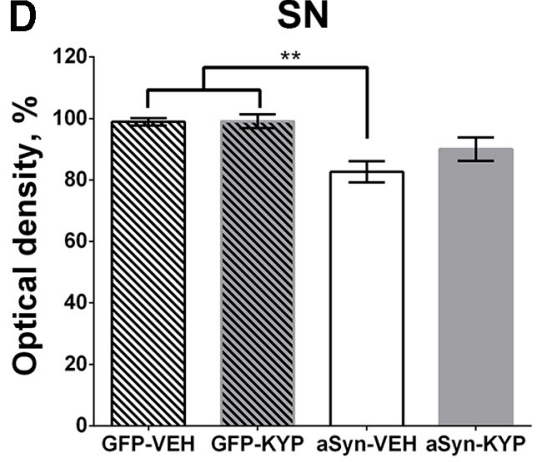

Figure 5. TH + cell amount and TH + immunoreactivity in striatum (STR) and SN showed mild loss of TH+ staining. $\boldsymbol{A}$, Representative images of TH + immunoreactivity in STR and SN brain samples 8 weeks after AAV-GFP and AAV-aSyn injections. $\boldsymbol{B}, \mathrm{TH}+$ cell stereology did not yield statistical significance between groups $\left(F_{(3,28)}=2.784, p=0.0593\right)$. $\boldsymbol{C}, \boldsymbol{D}, \mathrm{TH}+$ optical density in STR and SN shows significantly decreased TH + immunoreactivity in the vehicle-treated aSyn injection group in both areas (aSyn-VEH) compared to the GFP-injection control groups (GFP-KYP and GFP-VEH), while a similar decrease was not seen in the aSyn-injected KYP-2047-treated group (aSyn-KYP). $n=7-9$ mice/group. Error bars represent means \pm SEM. * $p<0.05 ;{ }^{* *} p<0.01$ (one-way ANOVA with Tukey's post hoc comparison).

ioral deficit has been restored by a treatment in a virus vectorbased aSyn rodent model. Even though animal numbers had to be reduced before the 8 week time point because of delivery method-related skin lesions, motor behavior results remained significant after the 6 week time point. The current study supports our previous observations where inhibition of PREP in a transgenic mouse model was followed by decreased aSyn aggregate amount and increased aggregate clearance via enhanced autophagy (Myöhänen et al., 2012; Savolainen et al., 2014), and further emphasizes the possibilities of small-molecule PREP inhibitors as drug candidates for PD and other synucleinopathies.

Neuronal aSyn inclusions and Lewy neurite-like formations in SNpr were visible 8 weeks after virus vector delivery, which correlated with the spontaneous forelimb bias. Although, we used undiluted high-titer aSyn viral injections above the SNpc, which might explain our motor and neurochemical results at an early stage after the aSyn virus vector injections. Previous studies have seen mixed results with mild DAergic cell loss or insignificant changes in spontaneous forelimb use (St Martin et al., 2007; Oliveras-Salvá et al., 2013; Fischer et al., 2016). Most of the transgenic aSyn mouse models have not showed evidence of significant loss of DA neurons in SN, but still report motor behavior disturbances (for details, see Eschbach and Danzer, 2014). Additionally, we saw a robust increase in aSyn oligomeric species in our mouse model after AAV-aSyn injections that correlated with DAergic and behavioral deficits. Interestingly, when treated with $\mathrm{PK}$, aSyn oligomer-specific staining was partially retained, suggesting PK-resistant species in mouse brain already at 2 months after AAV-aSyn injections. Nevertheless, the amount of PKresistant oligomers represented in the brain was 10 -fold smaller compared to the non-PK-treated brains in both vehicle- and KYP-2047-treated groups. This suggests that KYP-2047 mainly 

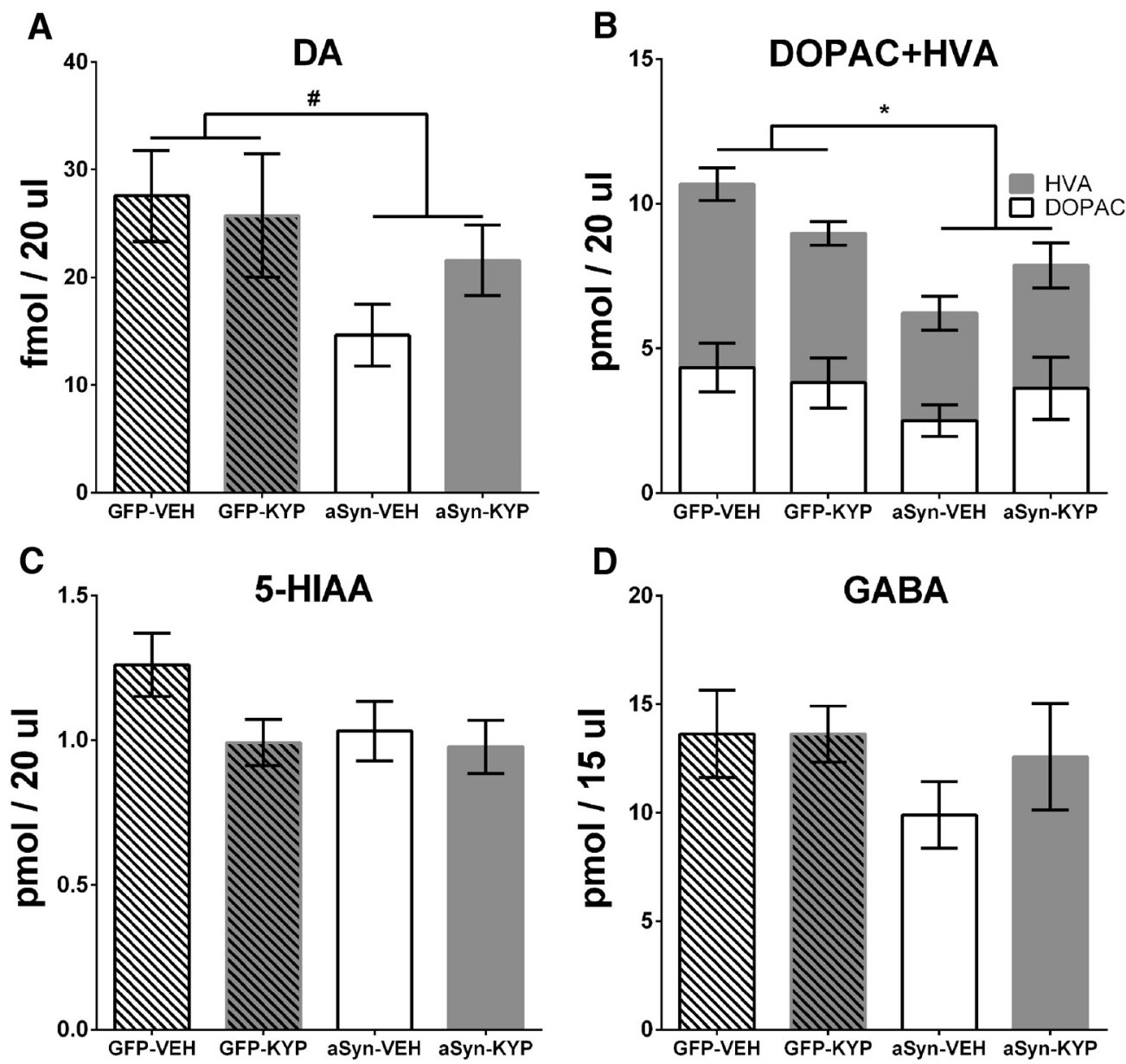

Figure 6. Overexpression of aSyn decreases extracellular DA and its metabolites in striatum in mice. $\boldsymbol{A}-\boldsymbol{D}$, After AAV-GFP $(n=19)$ or AAV-aSyn $(n=18)$ injection above the SNpc and 4 weeks of treatment with KYP-2047 or vehicle started 4 weeks postinjection, extracellular concentrations of DA $(\boldsymbol{A})$, its metabolites DOPAC and HVA $(\boldsymbol{B}), 5$-HIAA $(\boldsymbol{C})$, and GABA (D) were measured by striatal microdialysis. Overexpression of aSyn decreased extracellular concentrations of DOPAC and HVA (B), and there was a similar trend for DA (A). Although KYP-2047 elevated the levels of extracellular $D A$, treatment did not have a statistically significant effect on DA or its metabolites. Virus injection or treatments did not have a statistically significant effect on extracellular 5 -HIAA (C) or GABA (D). Error bars represent means \pm SEM. ${ }^{*} p<0.05 ;{ }^{*} p=0.061$ (two-way ANOVA).

has an effect on soluble aSyn aggregates, with the PK-resistant fraction representing an oligomeric pool acquired before treatment initiation. Cremades et al. (2012) showed that PK-resistant aSyn oligomers can be generated in initial stages at physiological concentrations, and PK-resistant species have been observed in presynaptic terminals in both transgenic animals (Tanji et al., 2010; Spinelli et al., 2014) and human disease with LBs, and they propose a mechanism that causes synaptic disturbances that are preceded by overt $\mathrm{TH}+$ neuron loss (Kramer and SchulzSchaeffer, 2007). Our results suggest that AAV-aSyn injection caused an increase in both soluble and insoluble forms of oligomers, while evidence in the literature points to soluble aggregate forms being more toxic than insoluble aggregates (Karpinar et al., 2009; Winner et al., 2011; Rockenstein et al., 2014).

Moreover, our results show the aSyn-mediated malfunction of the DAergic system before a significant loss in $\mathrm{TH}+$ neuron population, as aSyn overexpression models are thought to mediate presynaptic deficits in vesicle genesis and recycling that leads to reduced DA release (Nemani et al., 2010; Gaugler et al., 2012), heterogeneity, and enlargement of synaptic vesicles (Scott et al., 2010). Besides, the aSyn-SNARE-complex assembly and inhibition of SNARE-mediated vesicle docking by aSyn oligomers might be one of the reasons for neurodegeneration (Burré et al., 2010; Choi et al., 2013). Mild TH+ cell loss was consistent with our groups' observation in this study, and similar observations in mice were reported previously (Dong et al., 2002; St Martin et al., 2007; Theodore et al., 2008; Yasuda et al., 2009; Ulusoy et al., 2012). Nonetheless, we saw a decrease in extracellular and tissue DA and its metabolite levels in the nigrostriatal tract of mice, and changes in 5-HT or 5-HIAA levels were observable in striatal and nigral tissue. Gaugler et al. (2012) demonstrated that spontaneous motor asymmetry in the cylinder test after overexpression of aSyn is largely caused by impaired DA release with a minor loss of total striatal DA content in rats and in aged transgenic mice (Lam et al., 2011). Additionally, detailed analyses of postmortem PD patient brains have yielded evidence of initial loss of DA that precedes and overall exceeds DAergic cell loss (Kordower et al., 2013).

KYP-2047 treatment was started 4 weeks after AAV-aSyn injections, where spontaneous forelimb bias was lost in aSyn-KYP animals to GFP control group levels, with behavioral changes correlating with a significant decrease in aSyn oligomer numbers. It was shown previously that PREP inhibition reduces aSyn aggregation in cell-free conditions, in cells, and in vivo (Brandt et al., 2008; Myöhänen et al., 2012; Dokleja et al., 2014; Savolainen et al., 2015). Also, more recently, our group demonstrated a decrease in high-molecular-weight aSyn in transgenic mice (Savolainen et al., 2014). When PK treatment was used to establish aSyn 

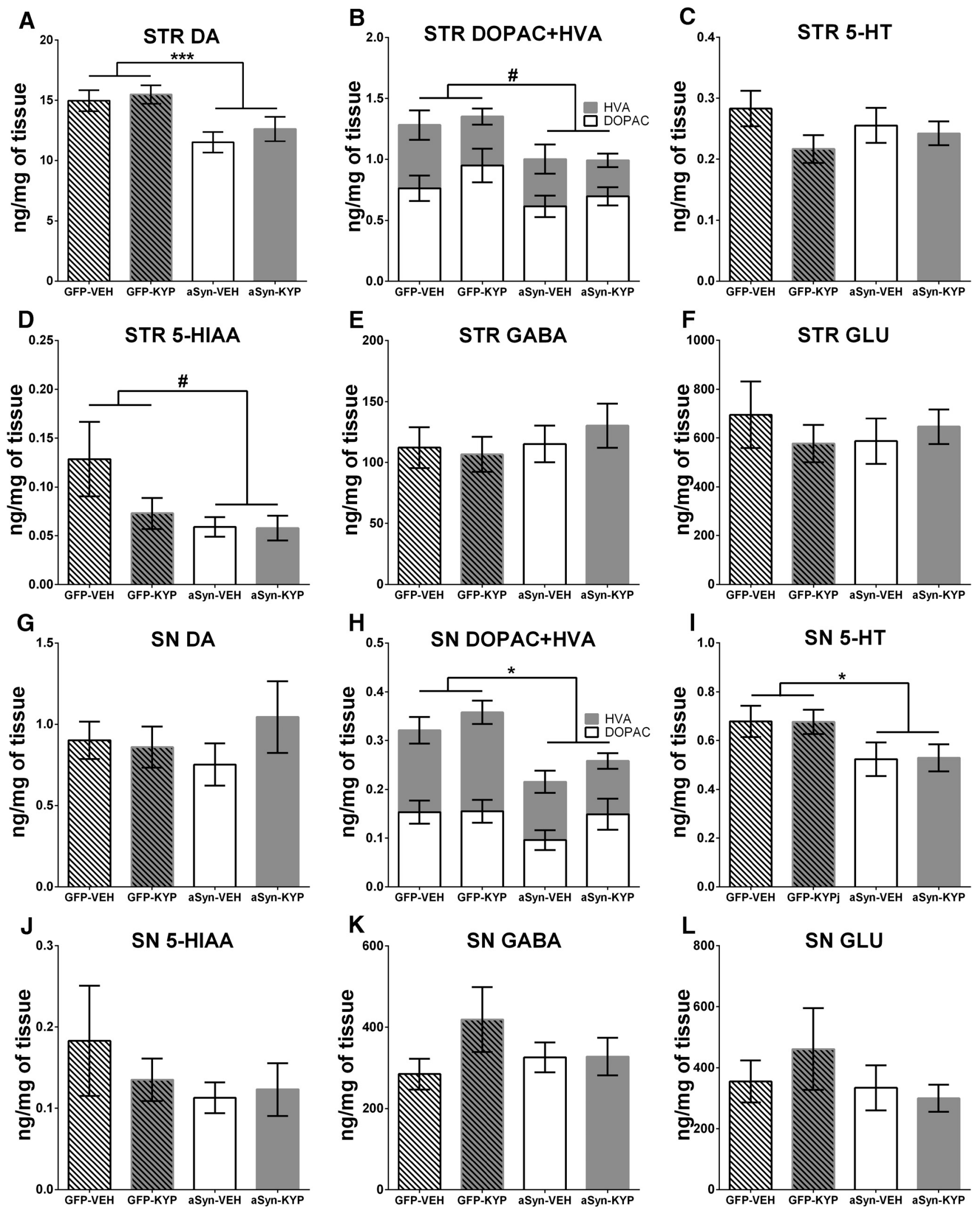

Figure 7. Overexpression of aSyn decreases neurotransmitters and their metabolites in nigrostriatal tissue. $\boldsymbol{A}-\boldsymbol{L}$, HPLC analysis was done after the viral vector injections and the treatment, and the tissue concentrations of DA $(\boldsymbol{A}, \boldsymbol{G})$, its metabolites DOPAC and HVA $(\boldsymbol{B}, \boldsymbol{H}), 5-H T(\boldsymbol{C}, \boldsymbol{I})$, its metabolite 5 -HIAA $(\boldsymbol{D}, \boldsymbol{J}), \mathrm{GABA}(\boldsymbol{E}, \boldsymbol{K})$, and glutamate $(\boldsymbol{F}, \boldsymbol{L})$ in striatum $(\mathrm{STR})$ and SN were measured. Overexpression of aSyn decreased the concentration of DA in striatal tissue $(\boldsymbol{A})$, and there was a similar trend for the metabolites of DA (B) and 5-HIAA (D) in STR. The concentration of DA was not changed in SN tissue $(\boldsymbol{G})$, but metabolites of DA $(\boldsymbol{H})$ and 5 -HT $(\boldsymbol{I})$ were decreased. KYP treatment did not have a statistically significant effect on DA, 5 -HT, or their metabolites, and virus injection or treatment did not have a statistically significant effect on tissue concentrations of GABA $(\boldsymbol{E}, \boldsymbol{K})$ or glutamate $(\boldsymbol{F}, \boldsymbol{L})$. Error bars represent mean $\pm \mathrm{SEM}$. ${ }^{*} p<0.05$; ${ }^{* * *} p<0.001 ;{ }^{*} p=0.060$ (tw0-way ANOVA). 
oligomer species in the mouse brain, PK-resistant aSyn oligomer formation was seen both in vehicle- and KYP-2047-treated mouse brains and could account for the fraction of deposits existing before KYP-2047 treatment. However, the overall distribution of PK-resistant oligomers was more robust in vehicle-treated brains, suggesting continued aggregate formation after treatment initiation in the vehicle group.

The aSyn mouse group that received KYP-2047 treatment had no significant loss of $\mathrm{TH}+$ staining either in striatum or $\mathrm{SN}$, and the loss of $\mathrm{TH}+$ cells in $\mathrm{SNpc}$ was less pronounced compared to vehicle-treated aSyn animals. Even though $\mathrm{TH}+$ cell loss was not significant when stereology method was applied, there was a clear trend in $\mathrm{TH}+$ cell loss in the vehicle-treated group and less pronounced $\mathrm{TH}+$ cell loss in KYP-2047-treated animals. Although we did not expect our compound to exert any neurorestorative properties on the DAergic neuron population, our results indicate that PREP inhibition can attenuate insults caused by aSyn overexpression after onset of behavioral and DAergic deficit and halt the progression of DAergic terminal degeneration in striatum and TH+ cell loss in SNpc. This was also observable in DA microdialysis, where KYP-2047 treatment had a beneficial effect on DA release, suggesting that reduced oligomerization restored, at least in part, the aSyn-regulated SNARE complex formation leading to the improved DA release. Additionally, aSyn regulates DA transporter (DAT) activity (Butler et al., 2015), and KYP2047 decreases DAT immunoreactivity (Savolainen et al., 2014), indicating that the alteration in DAergic function may also have DAT-mediated mechanisms.

Rescue of motor behavior and reduction in aSyn oligomers could be due to PREP's role as a negative regulator of the PI3K class III autophagy pathway. Particularly, inhibition of PREP by KYP-2047 results in increased autophagosome formation via alterations in beclin 1 expression levels. Thus, the effect of PREP inhibition on aSyn aggregation alters the aSyn seeding site on the PREP surface and induces autophagic flux that decreases highmolecular-weight aSyn (Savolainen et al., 2014) and total aSyn in aSyn transgenic mouse brain (Myöhänen et al., 2012). Notably, PREP directly interacts with aSyn, serving as a nucleation point for aSyn oligomerization, while KYP-2047 inhibition forces the PREP enzyme into a compact monomeric form that lacks the ability to form a connection with aSyn (Savolainen et al., 2015). Moreover, data from transgenic mice suggest that human aSyn is less efficiently cleared from the neuronal cytosol (Kahle et al., 2000), partially as a consequence of perturbations in the autophagy pathway (Cuervo et al., 2004; Spencer et al., 2009). Also, reduction of nonfunctional aSyn in nerve terminals after PREP inhibition could lift some of the aSyn negative regulatory effects (Savolainen et al., 2014).

In conclusion, by using a virus vector aSyn overexpression model in mice that was followed by PREP inhibition after the onset of motor symptoms, we were able to show that aSyn oligomer numbers in SN were decreased in the KYP-2047 treatment group. Decreases in oligomer amount had a beneficial effect on spontaneous motor behavior in cylinder test and on DAergic systems activity. Our study suggests that PREP inhibitors are compelling compounds for further characterization for the treatment of PD and other synucleinopathies.

\section{References}

Airavaara M, Mijatovic J, Vihavainen T, Piepponen TP, Saarma M, Ahtee L (2006) In heterozygous GDNF knockout mice the response of striatal dopaminergic system to acute morphine is altered. Synapse 59:321-329. CrossRef Medline
Angot E, Steiner JA, Lema Tomé CM, Ekström P, Mattsson B, Björklund A, Brundin P (2012) Alpha-synuclein cell-to-cell transfer and seeding in grafted dopaminergic neurons in vivo. PLoS One 7:e39465. CrossRef Medline

Baba M, Nakajo S, Tu PH, Tomita T, Nakaya K, Lee VM, Trojanowski JQ, Iwatsubo T (1998) Aggregation of alpha-synuclein in Lewy bodies of sporadic Parkinson's disease and dementia with Lewy bodies. Am J Pathol 152:879-884. Medline

Bellani S, Sousa VL, Ronzitti G, Valtorta F, Meldolesi J, Chieregatti E (2010) The regulation of synaptic function by $\alpha$-synuclein. Commun Integr Biol 3:106-109. CrossRef Medline

Bellucci A, Navarria L, Zaltieri M, Missale C, Spano P (2012) Alphasynuclein synaptic pathology and its implications in the development of novel therapeutic approaches to cure Parkinson's disease. Brain Res 1432: 95-113. CrossRef Medline

Bendor JT, Logan TP, Edwards RH (2013) The function of $\alpha$-synuclein. Neuron 79:1044-1066. CrossRef Medline

Betzer C, Movius AJ, Shi M, Gai WP, Zhang J, Jensen PH (2015) Identification of synaptosomal proteins binding to monomeric and oligomeric $\alpha$-synuclein. PLoS One 10:e0116473. CrossRef Medline

Braak H, Braak E (2000) Pathoanatomy of Parkinson's disease. J Neurol 247:II3-II10. Medline

Brandt I, Gérard M, Sergeant K, Devreese B, Baekelandt V, Augustyns K, Scharpé S, Engelborghs Y, Lambeir AM (2008) Prolyl oligopeptidase stimulates the aggregation of $\alpha$-synuclein. Peptides 29:1472-1478. CrossRef Medline

Brännström K, Lindhagen-Persson M, Gharibyan AL, Iakovleva I, Vestling M, Sellin ME, Brännström T, Morozova-Roche L, Forsgren L, Olofsson A (2014) A generic method for design of oligomer-specific antibodies. PLoS One 9:e90857. CrossRef Medline

Burré J, Sharma M, Tsetsenis T, Buchman V, Etherton MR, Südhof TC (2010) $\alpha$-Synuclein promotes SNARE-complex assembly in vivo and in vitro. Science 329:1663-1667. CrossRef Medline

Butler B, Saha K, Rana T, Becker JP, Sambo D, Davari P, Goodwin JS, Khoshbouei H (2015) Dopamine transporter activity is modulated by $\alpha$-synuclein. J Biol Chem 290:29542-29554. CrossRef Medline

Choi BK, Choi MG, Kim JY, Yang Y, Lai Y, Kweon DH, Lee NK, Shin YK (2013) Large $\alpha$-synuclein oligomers inhibit neuronal SNAREmediated vesicle docking. Proc Natl Acad Sci U S A 110:4087-4092. CrossRef Medline

Chu Y, Kordower JH (2007) Age-associated increases of $\alpha$-synuclein in monkeys and humans are associated with nigrostriatal dopamine depletion: Is this the target for Parkinson's disease? Neurobiol Dis 25:134-149. CrossRef Medline

Cremades N, Cohen SI, Deas E, Abramov AY, Chen AY, Orte A, Sandal M, Clarke RW, Dunne P, Aprile FA, Bertoncini CW, Wood NW, Knowles TP, Dobson CM, Klenerman D (2012) Direct observation of the interconversion of normal and toxic forms of $\alpha$-synuclein. Cell 149:1048 1059. CrossRef Medline

Cuervo AM, Stefanis L, Fredenburg R, Lansbury PT, Sulzer D (2004) Impaired degradation of mutant $\alpha$-synuclein by chaperone-mediated autophagy. Science 305:1292-1295. CrossRef Medline

Dokleja L, Hannula MJ, Myöhänen TT (2014) Inhibition of prolyl oligopeptidase increases the survival of alpha-synuclein overexpressing cells after rotenone exposure by reducing alpha-synuclein oligomers. Neurosci Lett 583:37-42. CrossRef Medline

Dong Z, Ferger B, Feldon J, Büeler H (2002) Overexpression of Parkinson's disease-associated $\alpha$-synucleinA53T by recombinant adeno-associated virus in mice does not increase the vulnerability of dopaminergic neurons to MPTP. J Neurobiol 53:1-10. CrossRef Medline

Eschbach J, Danzer KM (2014) $\alpha$-Synuclein in Parkinson's disease: pathogenic function and translation into animal models. Neurodegener Dis 14:1-17. CrossRef Medline

Farrer M, Kachergus J, Forno L, Lincoln S, Wang DS, Hulihan M, Maraganore D, Gwinn-Hardy K, Wszolek Z, Dickson D, Langston JW (2004) Comparison of kindreds with parkinsonism and $\alpha$-synuclein genomic multiplications. Ann Neurol 55:174-179. CrossRef Medline

Fischer DL, Gombash SE, Kemp CJ, Manfredsson FP, Polinski NK, Duffy MF, Sortwell CE (2016) Viral vector-based modeling of neurodegenerative disorders: Parkinson's disease. In: Gene therapy for neurological disorders: methods and protocols (Manfredsson PF, ed), pp 367-382. New York: Springer. 
Fuchs J, Nilsson C, Kachergus J, Munz M, Larsson EM, Schüle B, Langston JW, Middleton FA, Ross OA, Hulihan M, Gasser T, Farrer MJ (2007) Phenotypic variation in a large Swedish pedigree due to SNCA duplication and triplication. Neurology 68:916-922. CrossRef Medline

Gaugler MN, Genc O, Bobela W, Mohanna S, Ardah MT, El-Agnaf OM, Cantoni M, Bensadoun JC, Schneggenburger R, Knott GW, Aebischer P, Schneider BL (2012) Nigrostriatal overabundance of $\alpha$-synuclein leads to decreased vesicle density and deficits in dopamine release that correlate with reduced motor activity. Acta Neuropathologica 123:653-669. CrossRef Medline

Gundersen HJ, Jensen EB, Kiêu K, Nielsen J (1999) The efficiency of systematic sampling in stereology-reconsidered. J Microsc 193:199-211. CrossRef Medline

Hannula MJ, Myöhänen TT, Tenorio-Laranga J, Männistö PT, GarciaHorsman JA (2013) Prolyl oligopeptidase colocalizes with $\alpha$-synuclein, $\beta$-amyloid, tau protein and astroglia in the post-mortem brain samples with Parkinson's and Alzheimer's diseases. Neuroscience 242:140-150. CrossRef Medline

Hof PR, Young WG, Bloom FE, Belichenko PV, Celio MR (2000) Comparative cytoarchitectonic atlas of the C57BL6 and 129 Sv mouse brains. Amsterdam: Elsevier.

Ibáñez P, Bonnet AM, Débarges B, Lohmann E, Tison F, Pollak P, Agid Y, Dürr A, Brice A (2004) Causal relation between alpha-synuclein gene duplication and familial Parkinson's disease. Lancet 364:1169-1171 CrossRef Medline

Iwai A, Masliah E, Yoshimoto M, Ge N, Flanagan L, de Silva HA, Kittel A, Saitoh T (1995) The precursor protein of non-A $\beta$ component of Alzheimer's disease amyloid is a presynaptic protein of the central nervous system. Neuron 14:467-475. CrossRef Medline

Jalkanen AJ, Hakkarainen JJ, Lehtonen M, Venäläinen T, Kääriäinen TM, Jarho E, Suhonen M, Forsberg MM (2011) Brain pharmacokinetics of two prolyl oligopeptidase inhibitors, JTP-4819 and KYP-2047, in the rat. Basic Clin Pharmacol Toxicol 109:443-451. CrossRef Medline

Jalkanen AJ, Piepponen TP, Hakkarainen JJ, De Meester I, Lambeir AM, Forsberg MM (2012) The effect of prolyl oligopeptidase inhibition on extracellular acetylcholine and dopamine levels in the rat striatum. Neurochem Int 60:301-309. CrossRef Medline

Jalkanen AJ, Leikas JV, Forsberg MM (2014) KYP-2047 penetrates mouse brain and effectively inhibits mouse prolyl oligopeptidase. Basic Clin Pharmacol Toxicol 114:460-463. CrossRef Medline

Jarho EM, Venäläinen JI, Huuskonen J, Christiaans JA, Garcia-Horsman JA, Forsberg MM, Järvinen T, Gynther J, Männistö PT, Wallén EA (2004) A cyclopent-2-enecarbonyl group mimics proline at the P2 position of prolyl oligopeptidase inhibitors. J Med Chem 47:5605-5607. CrossRef Medline

Jiang CH, Tsien JZ, Schultz PG, Hu Y (2001) The effects of aging on gene expression in the hypothalamus and cortex of mice. Proc Natl Acad Sci U S A 98:1930-1934. CrossRef Medline

Käenmäki M, Tammimäki A, Myöhänen T, Pakarinen K, Amberg C, Karayiorgou M, Gogos JA, Männistö PT (2010) Quantitative role of COMT in dopamine clearance in the prefrontal cortex of freely moving mice. J Neurochem 114:1745-1755. CrossRef Medline

Kahle PJ (2008) alpha-Synucleinopathy models and human neuropathology: similarities and differences. Acta Neuropathol 115:87-95. Medline

Kahle PJ, Neumann M, Ozmen L, Haass C (2000) Physiology and pathophysiology of $\alpha$-synuclein: cell culture and transgenic animal models based on a Parkinson's disease-associated protein. Ann N Y Acad Sci 920:33-41. Medline

Karpinar DP, Balija MB, Kügler S, Opazo F, Rezaei-Ghaleh N, Wender N, Kim HY, Taschenberger G, Falkenburger BH, Heise H, Kumar A, Riedel D, Fichtner L, Voigt A, Braus GH, Giller K, Becker S, Herzig A, Baldus M, Jäckle H, et al. (2009) Pre-fibrillar $\alpha$-synuclein variants with impaired $\beta$-structure increase neurotoxicity in Parkinson's disease models. EMBO J 28:3256-3268. CrossRef Medline

Kirik D, Björklund A (2003) Modeling CNS neurodegeneration by overexpression of disease-causing proteins using viral vectors. Trends Neurosci 26:386-392. CrossRef Medline

Kirik D, Rosenblad C, Burger C, Lundberg C, Johansen TE, Muzyczka N, Mandel RJ, Björklund A (2002) Parkinson-like neurodegeneration induced by targeted overexpression of alpha-synuclein in the nigrostriatal system. J Neurosci 22:2780-2791. Medline

Kordower JH, Olanow CW, Dodiya HB, Chu Y, Beach TG, Adler CH, Halli- day GM, Bartus RT (2013) Disease duration and the integrity of the nigrostriatal system in Parkinson's disease. Brain 136:2419-2431. CrossRef Medline

Kramer ML, Schulz-Schaeffer WJ (2007) Presynaptic $\alpha$-synuclein aggregates, not Lewy bodies, cause neurodegeneration in dementia with Lewy bodies. J Neurosci 27:1405-1410. CrossRef Medline

Lam HA, Wu N, Cely I, Kelly RL, Hean S, Richter F, Magen I, Cepeda C, Ackerson LC, Walwyn W, Masliah E, Chesselet MF, Levine MS, Maidment NT (2011) Elevated tonic extracellular dopamine concentration and altered dopamine modulation of synaptic activity precede dopamine loss in the striatum of mice overexpressing human $\alpha$-synuclein. J Neurosci Res 89:1091-1102. CrossRef Medline

Lambeir AM (2011) Interaction of prolyl oligopeptidase with $\alpha$-synuclein. CNS Neurol Disord Drug Targets 10:349-354. CrossRef Medline

Langston JW, Schüle B, Rees L, Nichols RJ, Barlow C (2015) Multisystem Lewy body disease and the other parkinsonian disorders. Nat Genet 47: 1378-1384. CrossRef Medline

Mijatovic J, Airavaara M, Planken A, Auvinen P, Raasmaja A, Piepponen TP, Costantini F, Ahtee L, Saarma M (2007) Constitutive Ret activity in knock-in multiple endocrine neoplasia type $\mathrm{B}$ mice induces profound elevation of brain dopamine concentration via enhanced synthesis and increases the number of TH-positive cells in the substantia nigra. J Neurosci 27:4799-4809. CrossRef Medline

Moriyama A, Nakanishi M, Sasaki M (1988) Porcine muscle prolyl endopeptidase and its endogenous substrates. J Biochem 104:112-117. Medline

Myöhänen TT, Venäläinen JI, García-Horsman JA, Piltonen M, Männistö PT (2008) Distribution of prolyl oligopeptidase in the mouse whole-body sections and peripheral tissues. Histochem Cell Biol 130:993-1003. CrossRef Medline

Myöhänen TT, Kääriäinen TM, Jalkanen AJ, Piltonen M, Männistö PT (2009) Localization of prolyl oligopeptidase in the thalamic and cortical projection neurons: a retrograde neurotracing study in the rat brain. Neurosci Lett 450:201-205. CrossRef Medline

Myöhänen TT, Hannula MJ, Van Elzen R, Gerard M, Van Der Veken P, García-Horsman JA, Baekelandt V, Männistö PT, Lambeir AM (2012) A prolyl oligopeptidase inhibitor, KYP-2047, reduces $\alpha$-synuclein protein levels and aggregates in cellular and animal models of Parkinson's disease. Br J Pharmacol 166:1097-1113. CrossRef Medline

Nemani VM, Lu W, Berge V, Nakamura K, Onoa B, Lee MK, Chaudhry FA, Nicoll RA, Edwards RH (2010) Increased expression of $\alpha$-synuclein reduces neurotransmitter release by inhibiting synaptic vesicle reclustering after endocytosis. Neuron 65:66-79. CrossRef Medline

Nolte WM, Tagore DM, Lane WS, Saghatelian A (2009) Peptidomics of prolyl endopeptidase in the central nervous system. Biochemistry 48 : 11971-11981. CrossRef Medline

Oliveras-Salvá M, Van der Perren A, Casadei N, Stroobants S, Nuber S, D’Hooge R, Van den Haute C, Baekelandt V (2013) rAAV2/7 vectormediated overexpression of alpha-synuclein in mouse substantia nigra induces protein aggregation and progressive dose-dependent neurodegeneration. Mol Neurodegen 8:1-14. CrossRef

Paxinos G, Franklin KBJ (1997) The mouse brain in stereotaxic coordinates. San Diego: Elsevier.

Rockenstein E, Nuber S, Overk CR, Ubhi K, Mante M, Patrick C, Adame A, Trejo-Morales M, Gerez J, Picotti P, Jensen PH, Campioni S, Riek R, Winkler J, Gage FH, Winner B, Masliah E (2014) Accumulation of oligomer-prone $\alpha$-synuclein exacerbates synaptic and neuronal degeneration in vivo. Brain 137:1496-1513. CrossRef Medline

Savolainen MH, Richie CT, Harvey BK, Männistö PT, Maguire-Zeiss KA, Myöhänen TT (2014) The beneficial effect of a prolyl oligopeptidase inhibitor, KYP-2047, on alpha-synuclein clearance and autophagy in A30P transgenic mouse. Neurobiol Dis 68:1-15. CrossRef Medline

Savolainen MH, Yan X, Myöhänen TT, Huttunen HJ (2015) Prolyl oligopeptidase enhances $\alpha$-synuclein dimerization via direct protein-protein interaction. J Biol Chem 290:5117-5126. CrossRef Medline

Schmitz C, Hof PR (2005) Design-based stereology in neuroscience. Neuroscience 130:813-831. CrossRef Medline

Scott DA, Tabarean I, Tang Y, Cartier A, Masliah E, Roy S (2010) A pathologic cascade leading to synaptic dysfunction in $\alpha$-synuclein-induced neurodegeneration. J Neurosci 30:8083-8095. CrossRef Medline

Singleton AB, Farrer M, Johnson J, Singleton A, Hague S, Kachergus J, Hulihan M, Peuralinna T, Dutra A, Nussbaum R, Lincoln S, Crawley A, Han- 
son M, Maraganore D, Adler C, Cookson MR, Muenter M, Baptista M, Miller D, Blancato J, et al. (2003) $\alpha$-Synuclein locus triplication causes Parkinson's disease. Science 302:841. CrossRef Medline

Spencer B, Potkar R, Trejo M, Rockenstein E, Patrick C, Gindi R, Adame A, Wyss-Coray T, Masliah E (2009) Beclin 1 gene transfer activates autophagy and ameliorates the neurodegenerative pathology in $\alpha$-synuclein models of Parkinson's and Lewy body diseases. J Neurosci 29:1357813588. CrossRef Medline

Spillantini MG, Goedert M (2000) The $\alpha$-synucleinopathies: Parkinson's disease, dementia with Lewy bodies, and multiple system atrophy. Ann N Y Acad Sci 920:16-27.

Spillantini MG, Schmidt ML, Lee VM, Trojanowski JQ, Jakes R, Goedert M (1997) [alpha]-Synuclein in Lewy bodies. Nature 388:839-840. CrossRef Medline

Spinelli KJ, Taylor JK, Osterberg VR, Churchill MJ, Pollock E, Moore C, Meshul CK, Unni VK (2014) Presynaptic alpha-synuclein aggregation in a mouse model of Parkinson's disease. J Neurosci 34:2037-2050. CrossRef Medline

St Martin JL, Klucken J, Outeiro TF, Nguyen P, Keller-McGandy C, CantutiCastelvetri I, Grammatopoulos TN, Standaert DG, Hyman BT, McLean PJ (2007) Dopaminergic neuron loss and up-regulation of chaperone protein mRNA induced by targeted over-expression of alpha-synuclein in mouse substantia nigra. J Neurochem 100:1449-1457. Medline

Tanji K, Mori F, Mimura J, Itoh K, Kakita A, Takahashi H, Wakabayashi K (2010) Proteinase K-resistant $\alpha$-synuclein is deposited in presynapses in human Lewy body disease and A53T $\alpha$-synuclein transgenic mice. Acta Neuropathologica 120:145-154. CrossRef Medline

Tenorio-Laranga J, Männistö PT, Storvik M, Van der Veken P, GarcíaHorsman JA (2012) Four day inhibition of prolyl oligopeptidase causes significant changes in the peptidome of rat brain, liver and kidney. Biochimie 94:1849-1859. CrossRef Medline

Theodore S, Cao S, McLean PJ, Standaert DG (2008) Targeted overexpression of human alpha-synuclein triggers microglial activation and an adap- tive immune response in a mouse model of Parkinson disease. J Neuropathol Exp Neurol 67:1149-1158. CrossRef Medline

Ulusoy A, Björklund T, Buck K, Kirik D (2012) Dysregulated dopamine storage increases the vulnerability to alpha-synuclein in nigral neurons. Neurobiol Dis 47:367-377. CrossRef Medline

Uversky VN (2007) Neuropathology, biochemistry, and biophysics of $\alpha$-synuclein aggregation. J Neurochem 103:17-37. Medline

Uversky VN (2011) Intrinsically disordered proteins from A to Z. Int J Biochem Cell Biol 43:1090-1103. CrossRef Medline

Vekrellis K, Xilouri M, Emmanouilidou E, Rideout HJ, Stefanis L (2011) Pathological roles of $\alpha$-synuclein in neurological disorders. Lancet Neurol 10:1015-1025. CrossRef Medline

Venäläinen JI, Juvonen RO, Forsberg MM, Garcia-Horsman A, Poso A, Wallen EA, Gynther J, Männistö PT (2002) Substrate-dependent, nonhyperbolic kinetics of pig brain prolyl oligopeptidase and its tight binding inhibition by JTP-4819. Biochem Pharmacol 64:463-471. CrossRef Medline

Venäläinen JI, Garcia-Horsman JA, Forsberg MM, Jalkanen A, Wallén EA, Jarho EM, Christiaans JA, Gynther J, Männistö PT (2006) Binding kinetics and duration of in vivo action of novel prolyl oligopeptidase inhibitors. Biochem Pharmacol 71:683-692. CrossRef Medline

Vihavainen T, Relander TR, Leiviskä R, Airavaara M, Tuominen RK, Ahtee L, Piepponen TP (2008) Chronic nicotine modifies the effects of morphine on extracellular striatal dopamine and ventral tegmental GABA. J Neurochem 107:844-854. CrossRef Medline

Winner B, Jappelli R, Maji SK, Desplats PA, Boyer L, Aigner S, Hetzer C, Loher T, Vilar M, Campioni S, Tzitzilonis C, Soragni A, Jessberger S, Mira $\mathrm{H}$, Consiglio A, Pham E, Masliah E, Gage FH, Riek R (2011) In vivo demonstration that $\alpha$-synuclein oligomers are toxic. Proc Natl Acad Sci U S A 108:4194-4199. CrossRef Medline

Yasuda T, Nihira T, Ren YR, Cao XQ, Wada K, Setsuie R, Kabuta T, Wada K, Hattori N, Mizuno Y, Mochizuki H (2009) Effects of UCH-L1 on $\alpha$-synuclein over-expression mouse model of Parkinson's disease. J Neurochem 108:932-944. CrossRef Medline 